\title{
Role of Protein Glycosylation in Host-Pathogen Interaction
}

\author{
Borong Lin ${ }^{1,2}$, Xue Qing ${ }^{3}$, Jinling Liao ${ }^{1,2,4}$ and Kan Zhuo ${ }^{1,2, *}$ \\ 1 Laboratory of Plant Nematology, South China Agricultural University, Guangzhou 510642, China; \\ boronglin@scau.edu.cn (B.L.); jlliao@scau.edu.cn (J.L.) \\ 2 Guangdong Province Key Laboratory of Microbial Signals and Disease Control, South China Agricultural \\ University, Guangzhou 510642, China \\ 3 College of Plant Protection, Nanjing Agricultural University, Nanjing 210095, China; qingxue@njau.edu.cn \\ 4 Guangdong Eco-Engineering Polytechnic, Guangzhou 510520, China \\ * Correspondence: zhuokan@scau.edu.cn; Tel.: +86-20-3829-7310
}

Received: 18 February 2020; Accepted: 16 April 2020; Published: 20 April 2020

\begin{abstract}
Host-pathogen interactions are fundamental to our understanding of infectious diseases. Protein glycosylation is one kind of common post-translational modification, forming glycoproteins and modulating numerous important biological processes. It also occurs in host-pathogen interaction, affecting host resistance or pathogen virulence often because glycans regulate protein conformation, activity, and stability, etc. This review summarizes various roles of different glycoproteins during the interaction, which include: host glycoproteins prevent pathogens as barriers; pathogen glycoproteins promote pathogens to attack host proteins as weapons; pathogens glycosylate proteins of the host to enhance virulence; and hosts sense pathogen glycoproteins to induce resistance. In addition, this review also intends to summarize the roles of lectin (a class of protein entangled with glycoprotein) in host-pathogen interactions, including bacterial adhesins, viral lectins or host lectins. Although these studies show the importance of protein glycosylation in host-pathogen interaction, much remains to be discovered about the interaction mechanism.
\end{abstract}

Keywords: glycoprotein; host; interaction; pathogen; resistance; virulence

\section{Introduction}

Glycosylation is the process by which a carbohydrate is attached to a target macromolecule, typically proteins and lipids. In respect to proteins, this process is called "protein glycosylation" and the newly formed molecule is called a "glycoprotein" [1]. Protein glycosylation is a widespread post-translational modification that is conserved among various organisms and most cells of a specific individual [2]. Such a process plays a significant role in protein folding, targeted transport, cellular localisation and activity [3]. In an organism, glycoproteins are involved in multiple biological processes: cell recognition, differentiation, development, signal transduction, and immunity response, etc. For pathogen-host interactions, the pathogenicity, on the one hand, and host resistance (susceptibility) on the other, can be attributed to the glycosylation, for instance, pathogen-secreted proteins, host cell-surface, and organelle-resident proteins [4]. Glycoproteins are found in various forms, e.g., enzymes (nuclease, protease, glycosidase) [5,6], peptide hormones (chorionic gonadotropin, luteinizing hormone, thyrotropin, erythropoietin) [7], antibodies [8], lectins [9], membrane bond proteins [10], collagen [11], and fibronectin [12], some of which have great significance for clinical medicine. Those glycoproteins discussed in this review, with roles in host-pathogen interactions, are listed in Table 1. 
Table 1. Glycoproteins discussed in this review.

\begin{tabular}{|c|c|c|c|c|}
\hline Glycoprotein & Organism & $\begin{array}{l}\text { Role of Protein } \\
\text { Glycosylation }\end{array}$ & $\begin{array}{l}\text { Glycoprotein } \\
\text { Subtypes }\end{array}$ & Reference \\
\hline $\begin{array}{l}\text { Mucins (Muc1, } \\
\text { Muc2, Muc5AC } \\
\text { Muc6 etc.) }\end{array}$ & $\begin{array}{l}\text { Homo sapiens, Mus } \\
\text { musculus }\end{array}$ & $\begin{array}{l}\text { Glycan-mediated adhesion, } \\
\text { colonization and immune } \\
\text { response of pathogens }\end{array}$ & \multirow{2}{*}{ O-linkage } & [13-17] \\
\hline $\begin{array}{l}\text { Hydroxyproline- } \\
\text { rich glycoproteins } \\
\text { (HRGPs) }\end{array}$ & $\begin{array}{l}\text { Lycopersicon sculentum, } \\
\text { Arabidopsis thaliana, } \\
\text { Boswellia serrata and } \\
\text { Boswellia carteri }\end{array}$ & $\begin{array}{l}\text { Affect HRGPs intra- and } \\
\text { inter-molecular cross-linking }\end{array}$ & & [18] \\
\hline StAPs & Solanum tuberosum & \multirow{8}{*}{$\begin{array}{l}\text { Stabilization and activation } \\
\text { of proteins }\end{array}$} & \multirow{24}{*}{$N$-linkage } & [19] \\
\hline HMW1 & Haemophilus influenzae & & & [20] \\
\hline Slp1 & \multirow{2}{*}{ Magnaporthe oryzae } & & & {$[21]$} \\
\hline BSA4 & & & & {$[22]$} \\
\hline CBH1 & Trichoderma reesei & & & [23] \\
\hline PCIPG2 & Phytophthora capsici & & & {$[24]$} \\
\hline MgGPP & Meloidogyne graminicola & & & {$[25]$} \\
\hline GrCLE & Globodera rostochiensis & & & [26] \\
\hline Rho GTPase & Homo sapiens & Inactivation of proteins & & [27] \\
\hline Hc-CPL-1 & Haemonchus contortus & \multirow{4}{*}{$\begin{array}{l}\text { Impact on protein stability } \\
\text { and antigenicity }\end{array}$} & & {$[28]$} \\
\hline gp120 & $\begin{array}{c}\text { Human } \\
\text { Immunodeficiency } \\
\text { virus }\end{array}$ & & & [29] \\
\hline E1 & Semliki Forest virus & & & {$[30]$} \\
\hline Hemagglutinin & Influenza virus & & & [31] \\
\hline LecA & \multirow{2}{*}{ Pseudomonas aeruginosa } & \multirow{11}{*}{$\begin{array}{l}\text { Stabilization and activation } \\
\text { of proteins }\end{array}$} & & [32] \\
\hline LecB & & & & \\
\hline Bab A & \multirow{2}{*}{ Helicobacter pylori } & & & {$[33]$} \\
\hline Lab A & & & & [17] \\
\hline ECP6 & Cladosporium fulvum & & & [34] \\
\hline LysM1 & Trichophyton rubrum & & & {$[35]$} \\
\hline PSL & Pisum sativum & & & [36] \\
\hline BpLec & Bothrops pauloensis & & & {$[37]$} \\
\hline Mincle & $\begin{array}{l}\text { Homo sapiens, Mus } \\
\text { musculus }\end{array}$ & & & {$[38,39]$} \\
\hline Dectin-1 & \multirow{2}{*}{ Homo sapiens } & & & [40] \\
\hline DC-SIGN & & & & {$[41,42]$} \\
\hline
\end{tabular}

Due to the structural variability of carbohydrate side chains, glycosylation increases the diversity of the proteome to a level unmatched by any other post-translational modifications [2]. While carbohydrate is universal in nature, only a few monosaccharides can serve as a donor in glycosylation. The main substrates in the protein glycosylation are hexose and its derivatives, including D-glucose [43], D-mannose [44], D-galactose [45], fucose [46], $\mathrm{N}$-acetyl-glucosamine [47], and galactosamine [48]. In some proteins, sialic acid (SA) or xylose are also the substrates of protein glycosylation $[49,50]$. During glycosylation, straight or branched oligosaccharides consisting of 2-20 monosaccharide units are covalently bonded with amino acid side chains in proteins to form glycoproteins, catalyzed by glycosyltransferases which located in the endoplasmic reticulum (ER) and Golgi complex [51]. 
According to the amino acid atom to which the carbohydrate chain is linked, the glycoproteins can be divided into $\mathrm{N}$-linked and $\mathrm{O}$-linked glycoprotein subtypes [2] (Figure 1). Protein modification by structurally varying glycosylation can either be favourable or disadvantageous for the infected organism, as it affects both, the host resistance and the pathogen virulence. In this review, we summarize the roles of protein glycosylation in pathogen-host interactions.

A

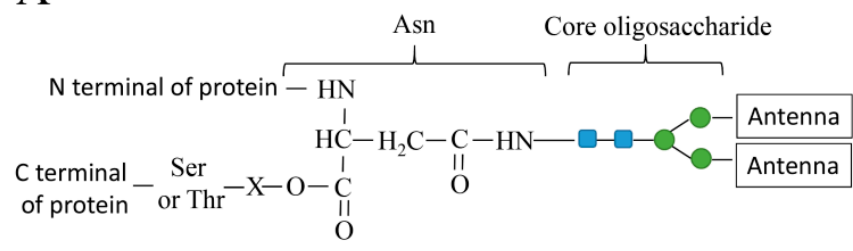

B

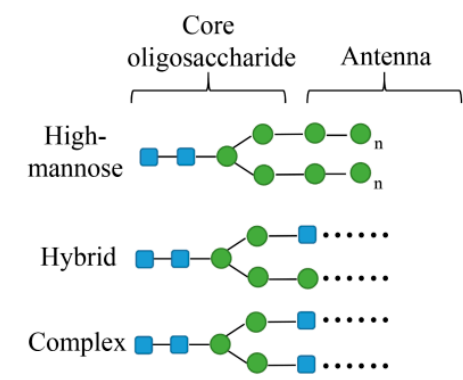

$\mathrm{C}$

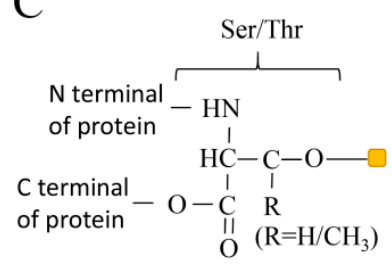

Mucin-type proteins

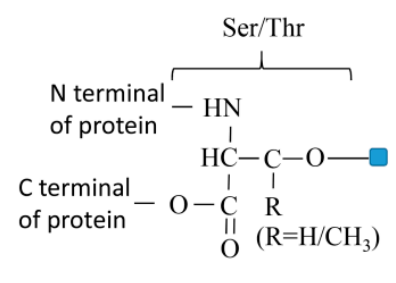

Cytoplasm/secreted protein

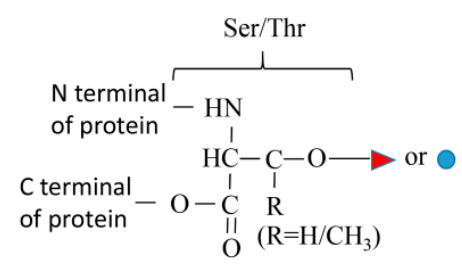

EGF

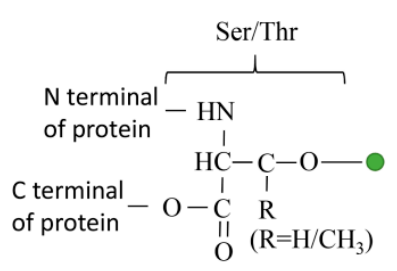

Cadherin/dystroglycan/O-Man

$\square$ GlcNAc OD-Mannose $\square$ GalNAc $\longrightarrow$-Fucose OD-Glucose $\bigcirc$-Galactose $₫$ L-Arabinose

Figure 1. Diagram showing the structure of $N$-linked and $O$-linked glycosylation types. (A) $N$-linked glycoprotein. The core oligosaccharide links to the amide nitrogen of asparagine (Asn) in the consensus sequence Asn-X-Ser/Thr (Ser, Thr, and X represent the serine, threonine and random amino acids). (B) Different subtypes of $N$-glycoproteins. High-mannose, oligosaccharide chains linked to the core oligosaccharide via mannose; Hybrid, oligosaccharide chains linked to the core oligosaccharide via GlcNAc and mannose; Complex, oligosaccharide chains linked to the core oligosaccharide via GlcNAc. (C) O-linked glycoprotein, oligosaccharides are bonded to the hydroxyl of Ser, Thr, hydroxylysine $(\mathrm{HyL})$ or hydroxyproline $(\mathrm{HyP})$ of proteins. Although the $\mathrm{O}$-linked glycoprotein has no core oligosaccharide, constant protein-glycans linkage was found in some types of proteins, such as GalNAc-Ser/Thr linkage found in Mucin-type proteins, L-fucose- or D-glucose- Ser/Thr linkage found in epidermal growth-factor-like repeats (EGF), D-mannose- Ser/Thr linkage found in Cadherin, dystroglycan or fungi and prokaryotes glycoproteins (Cadherin/dystroglycan/O-Man), GlcNAc- Ser/Thr linkage found in nucleocytosol glycoproteins or secreted glycoproteins in eukaryotic cells except yeast (Cytoplasm/secreted protein), D-galactose- or L-arabinose- HyP linkage found in hydroxyproline-rich glycoproteins (HRGPs) and D-galactose- HyL linkage found in Collagen.

\section{Host-Pathogen Interactions}

Host-pathogen interactions (HPIs) are complex and dynamic in nature and crucial for our understanding of infectious diseases. Most studies on HPIs primarily focus on how pathogens attack and exploit hosts, e.g., how pathogen invades hosts, evades from host defense, and proliferates in 
hosts, and in turn how host protects themselves against pathogens, e.g., how host immune responds to invaders [52].

Pathogen invasion starts from penetration into the host. Several ways of entry or pathways can be used, such as entering or (and) adhering to wounds on the host (cells) surface, mucosa membrane or natural orifices [53,54]. After entering hosts, pathogens interact with host cells for their survival and proliferation, with different targets and in specific mechanisms. For instance, viral pathogens invade host cells by merging their envelope with the membrane of host cells [55]; parasitic nematodes, fungi or bacteria can use special secretion systems to release effectors into host cells, manipulating some physiological and biochemical processes in hosts [56-58]; fungi also can utilize effectors on their hyphae surface to target host cell receptors and induce the endocytosis or cellular uptake of pathogens [59]. Pathogens may also interact with the host immune system, including the triggering of host immune responses and the pathogen evasion from these. Host immune responses are stepwise, first triggered by pathogen conserved molecules recognized by host-specific receptors. Then, through signal pathways, the defense signals are transmitted to the out- or in-side of cells. Finally, hosts receive the defense signals and then activate defense responses to tackle pathogens. Pathogens might attack any defense steps, they can evade recognition by host receptors through changing or masking their conserved molecules [60-63]. Invaders also may sabotage defense responses through disturbing the activity of key proteins or degrading signal molecules, which are related to a variety of defense responses or function in inhibiting the growth of pathogens or killing pathogens directly $[59,64,65]$.

Proliferation is essential for a successful pathogen invasion. This process is normally accomplished by manipulating the host cellular machinery in different ways. The acellular pathogens, like a virus, viroid or prion, usually utilize nucleic acid or host protein synthesis pathways to replicate itself $[66,67]$; while cellular pathogens, such as fungi, bacteria, protozoon or nematodes, gain only nutrients from hosts but utilize their own cellular machinery for proliferation $[58,68]$. In this scenario, they need to secrete effectors into hosts, altering the host energy metabolism pathway or transferring nutrients to the infection site.

On the whole, most of these processes can be mediated via protein-protein interactions, including cell surface protein interactions between hosts and pathogens, host cell surface protein and pathogen effector protein interactions, host-secreted protein and pathogen effector protein interactions, and host-secreted protein and pathogen cell surface protein interactions. These proteins often undergo glycosylation during their maturation, playing a significant role in host-pathogen interactions. For example, epithelial human blood group antigens (HBGAs) on $O$-glycans function in adherence and invasion of pathogens [69]. Mucin MUC5AC, which is glycosylated by HBGAs (Lewis b), can promote Helicobacter pylori infection, but mucin MUC6 glycosylated by GlcNAc-capped glycans, can inhibit H. pylori infection $[16,33]$. In general, protein glycosylation in host strongly impacts pathogen binding and invasion [70-72].

\section{Glycosylated Proteins of Hosts Act as Barriers to Defense Pathogens}

Animals and plants are exposed to an array of pathogens, but only a few can actually cause severe diseases [73,74]. This is because the attack of most pathogens is blocked by glycosylated proteins covering the host cell surface as barriers. Such barriers may act in two manners in host defense, (I) physically separate pathogens and host cells [75,76]; (II) chemically inhibit or kill pathogens [16,77-79].

\subsection{Physical Barrier}

In animals, the physical contact of the pathogen to epithelial cells can be prevented by a rigid or visco-elastic gel formed by secretory oligomerized mucins [80]. Heavily O-glycosylated mucins forming a dense mucus layer can prevent the attachment of parasitic nematodes (e.g., Nippostrongylus brasiliensis) [81]. In contrast, after the mucus layer was removed by mustard oil, cysteine protease or papain, the intestinal colonization of N. brasiliensis was increased [80,82]. Likewise, the study of Trichuris muris infection in mice suggests that expression of the mucins was exclusively induced in T. muris 
resistant mice. These mucins promoted T. muris to be expelled from intestinal tracts, and accordingly, a knock-out of the mucin gene abolished protective functions in the host [15]. A similar protective phenomenon was also observed during the infection of Trichostrongylus colubriformis, Trichinella spiralis, Helicobacter pylori and Hymenolepis diminuta [16,83-85]. In addition, cell surface mucins like MUC1 contribute to the formation of the apical cell glycocalyx in wet-surfaced epithelia, inhibiting the infection of Corynebacteria and coagulase-negative Staphylococci [86]. It's worthy to note that mucins, especially secretory mucins also involve in promoting pathogen infection via adhesions on the pathogen, as discussed in Section 7 (lectin, a class of protein entangled with glycoprotein, affects host-pathogen interactions).

In plants, hydroxyproline-rich glycoproteins (HRGPs) which are characterized by a rigid polyproline type II (PPII) conformation and extensive O-glycosylation of 4 (R)-hydroxy-l-proline residues [87], can physically inhibit pathogen penetration [88]. HRGPs play a leading role in plant defense, e.g., HRGPs were induced in incompatible plant-pathogen interactions $[18,89]$ and rapidly deposited in the cell wall after pathogen infection $[90,91]$. Such a defense ability is a result of the intra- and inter-molecular cross-linking in plant cell walls after HRGPs become insolubilized [88,92]. In this process, the interaction between insoluble HRGPs and the polysaccharide reduces the hydration and pectin mobility of the cell wall thus leading to the increase of rigidity and resistance of cell wall against pathogen invasion [92]. Furthermore, it was found that intra- and inter-molecular cross-linking took place in glycosylated HRGPs under the catalysis of the peroxidase. However, the deglycosylated HRGPs could not be cross-linked [18], suggesting that glycosylation contributes to the HRGPs network formation.

\subsection{Chemical Barrier}

In animals, the glycoproteins facilitate the growth of probiotics in the gut thus provides a chemical barrier against pathogens [93]. The O-glycans of glycoproteins like MUC2 can serve as attachment sites for probiotic colonization [13,94] by providing favorable nutrition substances [95]. Consequently, intestinal surface harbors a complex ecosystem consisting of a myriad of intestinal microorganisms that affect the physiology, immune function, and fitness of the host [96]. Among those probiotics including Bifidobacterium and Lactobacillus are considered as the key players to exert health-promoting effects [94].

Glycoproteins can also eliminate gut pathogens comparable to antibiotics [16]. Helicobacter pylori is a severe pathogen that infects the stomachs of nearly half of human population. It widely presents in stomachs but rarely in deeper portions of the gastric mucosa that coated by the mucus $[97,98]$. Kawakubo et al. [16] discovered that the special $O$-linked carbohydrate terminal, $\alpha(1,4)$-GlcNAc, and the mucins (comprising of Muc6) with $\alpha(1,4)$-GlcNAc expressed in the gastric mucosa have activity against $H$. pylori by inhibiting the biosynthesis of the cell wall.

In plants, glycosylation can stabilize plant extracellular proteinases and regulate their activities against pathogen invasion. Usually, the active sites of plant extracellular proteinases are protected by $\mathrm{N}$-carbohydrate residues during glycosylation to avoid the proteolytic process introduced by other proteases [5]. For example, the aspartic proteinases (StAPs) are extracellular proteinase from potato which have in vitro antifungal activity towards Phytophthora infestans and Fusarium solani $[19,77,99]$. In apoplast StAPs accumulated significant more in the P. infestans resistant cultivar than in susceptible cultivar [19], accumulated slower when unglycosylated than glycosylated, and the fungicidal activity of deglycosylated StAPs was lower than native StAPs [5].

\section{Glycosylated Proteins of Pathogens Act as Weapons to Attack the Host}

Glycosylated proteins are involved in both pathogen infection and host defense to pathogens. In pathogens, cell surface proteins and secretory proteins are the main glycoproteins that can promote infection. 


\subsection{Cell Surface Glycoproteins}

Host cell adhesion is important for infection initiation, and such a process is mediated by pathogen cell surface glycoproteins [100-103]. One example is the cell surface glycoprotein HMW1 in Haemophilus influenzae. It can mediate bacterial adhesion by interacting with a specific receptor on the human cell surface [104]. The activity of HMW1 relies on the other two proteins HMW1B and HMW1C, the former is inserted into the bacterial outer membrane, mediating the HMW1 to display on the cell surface [105], while the latter with glycosyltransferase activity can catalyse glycosylation of HMW1 in the cytoplasm [20]. The HMW1 is tethered to the bacterial surface by the glycans. However, deglycosylation HMW1 sheds from the bacterial cell membrane. The deficiency of HMW1 inhibits bacterial adhesion to host epithelial cells, suggesting HMW1 is bound to the bacterial surface only after glycosylation [101].

\subsection{Secreted Glycoproteins}

Increasing secreted proteins, or called effector, contribute to the virulence of pathogens $[25,106]$. Some effectors must undergo glycosylation to activate their function. A typical example is LysM Protein1 (Slp1) secreted by the rice blast fungus Magnaporthe oryzae. Slp1 is a critical virulence factor for M. oryzae that can bind with the fungal pathogen-associated molecular pattern (PAMP) chitin to escape the PAMP perception by the rice (Oryza sativa) chitin elicitor binding protein (CEBiP), such that rice blast fungus can successfully evade host innate immune [21]. The activity and stability of the chitin-binding of Slp1 depend on the existence of $N$-glycosylation. Specifically, Slp1 is unable to bind chitin and degrades significantly faster without glycosylation. Nonglycosylated Slp1 results in higher free chitin build-up that is more recognizable by CEBiP and, in turn, triggering plant innate immunity responses [22]. Other effectors like BAS4 (from M. oryzae) [22], CBH1 (from Trichoderma reesei) [23], and PCIPGII (from Phytophthora capsici) [24] also confirm N-glycosylation as an essential factor for pathogen virulence.

The glycans are covalently linked to effectors within the fungus cells. However, effectors from plant-parasitic nematodes can recruit host post-translational machinery rather than their own to fulfill glycosylation. As an example, the effector MgGPP secreted by the rice root-knot nematode Meloidogyne graminicola promotes parasitism by suppressing plant defenses, but only validate after $N$-glycosylation. Interestingly, this $N$-glycosylation occurs in the ER of host cells instead of M. graminicola cells [25]. Similarly, the effector GrCLE in the cyst nematode Globodera rostochiensis is also glycosylated using the host cellular machinery, following secretion into plant cells. The arabinosylation of the GrCLE is crucial for successful parasitism by binding a CLAVATA2-like receptor (StCLV2) from potatoes to regulate plant development [26].

Regardless the limited evidence available, plant-parasitic nematodes are unlikely to $N$-glycosylate effectors by their own post-translational machinery for three possible reasons: (I) no glycosyltransferase is expressed in esophageal gland cells (the key effector's generator in plant-parasitic nematodes); (II) there is no appropriate glycan donor in esophageal gland cells; (III) the consensus domains in $\mathrm{N}$-glycosylation proteins from plant-parasitic nematodes are unique. Therefore, the effector is likely to be $\mathrm{N}$-glycosylated in host cells rather than ER-Golgi apparatus in esophageal glands. This special mechanism in plant-parasitic nematodes may have evolutionary merit in evading host immunity.

\section{Proteins of the Host Are Glycosylated by Pathogens to Enhance Virulence}

Pathogens are capable of glycosylating self-proteins and host proteins to enhance their virulence. Toxin A (TcdA) and toxin B (TcdB) are two predominant virulence factors of the bacillus Clostridium difficile, they can glycosylate the host Rho GTPases which otherwise cannot be glycosylated [107]. Both TcdA and TcdB contain a glucosyltransferase domain in $\mathrm{N}$-terminal, conferring cytopathic and cytotoxic effects in intoxicated host cells [108,109]. TcdA/B enters into host cells through endocytosis [27], selectively modifies the host Rho GTPases by mono-O-glucosylation, and subsequently cause inhibitory 
effects $[109,110]$. This interaction is remarkable since Rho GTPase is the key member involved in various biological processes and signaling pathways [111]. The inactivation of Rho GTPase would block signal transmissions and regulatory functions, and resulting in cell morphological changes [112], apoptosis [113], phagocytosis dysregulation [114], pseudomembranous colitis and antibiotic-associated diarrhea in hosts [107].

\section{Hosts Sense Glycoproteins of Pathogens to Induce Resistance}

Pathogen glycoprotein is used both by pathogens and hosts. It can facilitate infection by increasing pathogen pathogenicity but also triggering the host immune response. During the invasion of parasitic helminthes, proteases are secreted [115] and glycosylated to activate their function in degrading multiple host defensive proteins, and subsequently suppress and modulate host immune response [28]. Cysteine protease (Hc-CPL-1) is essential for the parasitism of Haemonchus contortus. Interestingly, Hc-CPL-1 is recognized by the host protective antibody to induce immunity [116]. Recombinant cysteine protease (rHc-CPL-1) that expressed in E. coli only induces weaker immunity responses in sheep than the original Hc-CPL-1 [117]. Previous studies have reported that carbohydrate chains are covalently linked in original HcCPL-1 but absent in rHc-CPL-1. The host protective antibody mainly recognized glycan epitopes for triggering defenses [117], showing that the glycosylation of Hc-CPL-1 plays a major role in parasite recognition. Similarly, glycoproteins of other pathogens, like hemagglutinin of influenza viruses [31], glycoprotein E1 of alphavirus [30,118] and envelope protein (gp120) of HIV [29], are also recognized by hosts to inhibit pathogen invasion. They all can be bound by the host retrocyclin 2 (RC2) to inhibit virus infection, but the deglycosylation form can't be bound by RC2 [31].

\section{Lectin, a Class of Protein Entangled with Glycoprotein, Affects Host-Pathogen Interactions}

The first lectin is ricin identified in protein extracts from castor seed in 1888 [119]. After that, more than 1000 similar proteins have been found in animals, plants, and microorganisms. Most of these proteins can agglutinate erythrocyte and named as lectin [120]. Lectin usually contains at least one non-catalytic carbohydrate-binding domain (CBD). It can reversibly and specifically bind free sugars or glycans of glycoprotein and glycolipid (a lipid that contains carbohydrate radical) while keeping the structure of the glycans $[102,119]$. Lectins are placed in a super heterogeneous protein family, various in molecular structure, carbohydrate-binding specificity, and biological activities. The validation of the current classification system of lectins is subject to discussion. The two widely used lectin classification systems are either based on the sugar-binding property or on the structure of CBD. In the first system, lectins are grouped as mannose-binding lectins, galactose-binding lectins, and chitin-binding lectins. However, this system is problematic, as lectins prefer oligosaccharides or complex glycans than monosaccharides, and it ignores evolutionary or sequence relationships. The CBD based system emerges and gradually becomes the key for lectin classification. The CBD is characterized by its specific amino acid sequence, typical folding of the lectin polypeptide, and the binding site structure. In this system, lectins can be split into at least 24 families. Among them 12 present in animals and 12 present in plants (Table 2) $[99,100]$. Besides, lectins can also be assigned based on the domain architecture, resulting merolectins (contain a single CBD), hololectins (contain two or more same $\mathrm{CBDs}$ ), chimerolentins (contain $\mathrm{CBD}(\mathrm{s})$ and other domains independent from lectin domain) and superlectins (contain two different CBDs) [99]. 
Table 2. The lectin families in animals and plants.

\begin{tabular}{|c|c|c|c|c|}
\hline Family & $\begin{array}{l}\text { Subcellular } \\
\text { Localization }\end{array}$ & $\begin{array}{c}\text { Carbohydrate-Binding } \\
\text { Specificity }\end{array}$ & Main Function & Reference \\
\hline \multicolumn{5}{|c|}{ Animals } \\
\hline Calnexins & $\begin{array}{l}\text { Endoplasmic } \\
\text { reticulum (ER), cell } \\
\text { membrane }\end{array}$ & $\mathrm{Glc}_{1} \mathrm{Man}_{9}$ oligosaccharide & $\begin{array}{l}\text { Molecular chaperones } \\
\text { during glycoprotein } \\
\text { synthesis }\end{array}$ & [121-123] \\
\hline L-type lectins & $\begin{array}{l}\text { ER, Golgi, ER-Golgi } \\
\text { intermediate } \\
\text { compartment }\end{array}$ & High-mannose $N$-glycans & $\begin{array}{l}\text { Protein sorting in the } \\
\text { endoplasmic reticulum }\end{array}$ & {$[124,125]$} \\
\hline P-type lectins & $\begin{array}{l}\text { Cell membrane, } \\
\text { trans-Golgi network, } \\
\text { endosomes }\end{array}$ & 6-phosphorylated mannose & $\begin{array}{l}\text { Intracellular routing of } \\
\text { glycoconjugates }\end{array}$ & [126-130] \\
\hline C-type lectins & $\begin{array}{l}\text { Cell membrane, } \\
\text { extracellular }\end{array}$ & $\mathrm{N}$ - or O-glycans & $\begin{array}{c}\text { Cell adhesion, } \\
\text { glycoprotein clearance, } \\
\text { and innate immunity }\end{array}$ & {$[39,131]$} \\
\hline $\begin{array}{l}\text { Galectins } \\
\text { (S-type } \\
\text { lectins) }\end{array}$ & $\begin{array}{l}\text { Cytoplasm, cell } \\
\text { membrane, nuclear } \\
\text { extracellular }\end{array}$ & $\begin{array}{l}\text { Galactose, GalNAc, } \\
\text { mannose }\end{array}$ & $\begin{array}{l}\text { Cellular growth regulation } \\
\text { and extracellular } \\
\text { molecular bridging }\end{array}$ & {$[72,132-136]$} \\
\hline I-type lectins & Cell membrane & $\begin{array}{c}\text { Sialic acid, High mannose } \\
N \text {-linked on L1 (cis) } \\
N \text {-linked phosphacan, } \\
N \text {-glycans contain fucose }\end{array}$ & Cell adhesion & [137-139] \\
\hline R-type lectins & $\begin{array}{l}\text { Golgi, cell } \\
\text { membrane }\end{array}$ & Galactose, GalNAc & $\begin{array}{l}\text { Enzyme targeting, } \\
\text { glycoprotein hormone } \\
\text { turnover. }\end{array}$ & [140-142] \\
\hline F-box lectins & Cytoplasm & $\mathrm{GlcNAc}_{2}$ & $\begin{array}{l}\text { Degradation of misfolded } \\
\text { glycoproteins. }\end{array}$ & [143] \\
\hline Ficolins & $\begin{array}{l}\text { Cell membrane, } \\
\text { extracellular }\end{array}$ & GlcNAc, GalNAc & Self/non-self recognition & {$[144,145]$} \\
\hline $\begin{array}{l}\text { Chitinase-like } \\
\text { lectins }\end{array}$ & $\begin{array}{l}\text { Cell membrane, } \\
\text { extracellular }\end{array}$ & Chito-oligosaccharides & $\begin{array}{l}\text { Development, tissue } \\
\text { remodelling and } \\
\text { inflammation }\end{array}$ & [146-148] \\
\hline $\begin{array}{l}\text { F-type lectins } \\
\text { (fucolectins) }\end{array}$ & Extracellular & $\begin{array}{l}\text { Glycans terminal with } \\
\text { fucose }\end{array}$ & Innate immunity & {$[149,150]$} \\
\hline Intelectins & $\begin{array}{l}\text { Extracellular, cell } \\
\text { membrane }\end{array}$ & $\begin{array}{l}\text { Gal, galactofuranose, } \\
\text { pentoses }\end{array}$ & $\begin{array}{l}\text { Fertilization and } \\
\text { embryogenesis. }\end{array}$ & [151-153] \\
\hline \multicolumn{5}{|c|}{ Plants } \\
\hline $\begin{array}{l}\text { Agaricus } \\
\text { bisporus } \\
\text { agglutinin } \\
\text { homologs }\end{array}$ & $\begin{array}{l}\text { Nucleus, cytoplasm, } \\
\text { cell wall }\end{array}$ & $\begin{array}{c}\text { Glycans contain Gal or/and } \\
\text { GalNAc }\end{array}$ & Undetermined & [154-156] \\
\hline Amaranthin & Nucleus, cytoplasm & Gal- $\beta(1,3)$ GalNAc & $\begin{array}{l}\text { Anti phytophagous and/or } \\
\text { herbivorous animals }\end{array}$ & [157-159] \\
\hline $\begin{array}{l}\text { Chitinase-like } \\
\text { lectins }\end{array}$ & Undetermined & $\begin{array}{l}\text { High mannose } N \text {-glycans } \\
\text { comprising the proximal } \\
\text { pentasaccharide core } \\
\text { structure }\end{array}$ & $\begin{array}{c}\text { Defense response and } \\
\text { host-microbe interaction }\end{array}$ & {$[160,161]$} \\
\hline Cyanovirin-N & Undetermined & $\begin{array}{l}\text { High-mannose type } \\
N \text {-glycans }\end{array}$ & Undetermined & [162] \\
\hline $\begin{array}{l}\text { Euonymus } \\
\text { lectin }\end{array}$ & Nucleus, cytoplasm & $\begin{array}{c}\text { Blood group B } \\
\text { oligosaccharides, } \\
\text { high-mannose } N \text {-glycans }\end{array}$ & Regulate gene expression & [163-165] \\
\hline $\begin{array}{l}\text { Galanthus } \\
\text { nivalis } \\
\text { agglutinin }\end{array}$ & $\begin{array}{l}\text { Nucleus, cytoplasm } \\
\text { vacuolar }\end{array}$ & $\begin{array}{l}\text { Mannose, oligomannosides, } \\
\text { high-mannose and/or } \\
\text { complex type } N \text {-glycans }\end{array}$ & Undetermined & [166-168] \\
\hline
\end{tabular}


Table 2. Cont.

\begin{tabular}{|c|c|c|c|c|}
\hline Family & $\begin{array}{l}\text { Subcellular } \\
\text { Localization }\end{array}$ & $\begin{array}{l}\text { Carbohydrate-Binding } \\
\text { Specificity }\end{array}$ & Main Function & Reference \\
\hline Hevein & Vacuolar, cell wall & $\begin{array}{c}\text { Chito-oligosaccharides, high } \\
\text { mannose and/or complex } \\
N \text {-glycans, } \\
N \text {-acetyl-D-glucosamine }\end{array}$ & $\begin{array}{l}\text { Anti phytophagous and/or } \\
\text { herbivorous animals }\end{array}$ & $\begin{array}{c}{[161,169-} \\
171]\end{array}$ \\
\hline Jacalins & $\begin{array}{l}\text { Nucleus, cytoplasm, } \\
\text { vacuole }\end{array}$ & Mannose, galactose & $\begin{array}{l}\text { Development and defense } \\
\text { response }\end{array}$ & [172-175] \\
\hline Legume lectin & $\begin{array}{c}\text { Extracellular, } \\
\text { cytoplasm, vacuolar }\end{array}$ & $\begin{array}{l}\text { Sialic acid, mannose, } \\
N \text {-acetylgalactosamine, }\end{array}$ & $\begin{array}{c}\text { Anti phytophagous and/or } \\
\text { herbivorous animals, } \\
\text { defense response }\end{array}$ & [176-179] \\
\hline Lysin domain & $\begin{array}{l}\text { Cell membrane, } \\
\text { vacuolar }\end{array}$ & $N$-acetyl-D-glucosamine & $\begin{array}{l}\text { Perception and recognition } \\
\text { of pathogens }\end{array}$ & {$[21,180-183]$} \\
\hline Nictaba & Nucleus, cytoplasm, & $\begin{array}{l}N \text { - and } O \text {-glycans contain } \\
N \text {-acetyllactosamine, } \\
\text { high-mannose } N \text {-glycans }\end{array}$ & $\begin{array}{l}\text { Anti phytophagous and/or } \\
\text { herbivorous animals and } \\
\text { regulate gene expression }\end{array}$ & [184-186] \\
\hline $\begin{array}{l}\text { Ricin-B } \\
\text { family }\end{array}$ & $\begin{array}{l}\text { Nucleus, cytoplasm, } \\
\text { vacuolar }\end{array}$ & $\begin{array}{l}\text { Gal, GalNAc, glycans } \\
\text { contain sialic acid }\end{array}$ & $\begin{array}{l}\text { Anti phytophagous and/or } \\
\text { herbivorous animals }\end{array}$ & {$[187,188]$} \\
\hline
\end{tabular}

Lectins have a variety of functions in vivo, such as participating in host-pathogen interaction [72,182], inhibiting nutrition absorption [189], intercellular recognition [190], cell migration [191] and signal transduction [111]. These functions rely on the sugar-binding activity of lectins. During the host-pathogen interaction, lectins have an entangled relationship to glycoproteins. Except for some cases (e.g., capsid proteins of noroviruses [59], chitinase-like lectins [160,161] and galectins [192]), many immature lectins are covalently bound to the glycans. Although their exact role remains unknown, research has suggested glycans can promote the CBD stability [22]. After that, mature lectins can further bind other sugar or glycans via van der Waals forces [27]. The main role of glycans on proteins emerges through their interactions with lectins, like those on bacteria (e.g., Helicobacter pylori or Salmonella enteritidis) or on virus (e.g., influenza virus or human immunodeficiency virus).

\subsection{Pathogen Lectins}

Pathogen lectins usually promote infection by sensing hosts or suppressing host immunity. Host recognition is the prerequisite of a successful pathogen infection [193]. This process is affected by a variety of factors, among which lectins on the surface of pathogens and glycans on the surface of host cells ( $N$-linked or O-linked carbohydrate residues of glycolipids or glycoproteins) are crucial [194]. One typical example is the Influenza Virus (IAVs) surface glycoprotein haemagglutinin (HA). It is a trimeric lectin in IAVs that can help host recognition and further cytoplasm penetration through binding SA-containing glycoproteins on host cell membranes $[195,196]$. The subtypes of IAVs vary in host ranges depend on specific host recognition of HA [197], especially the differences in the glycosidic bonds of penultimate carbohydrate of the SA residue $[198,199]$. In avian respiratory epidermal cells, the linkage of penultimate carbohydrate of the SA residues is $\alpha-2,3$ glycosidic bonds, while it is $\alpha-2,6$ glycosidic bonds in human [200]. Based on amino acid sequences in the HA sugar-binding domain, avian-adapted IAVs preferentially bind $\alpha-2,3-\mathrm{SA}$ while it is $\alpha-2,6-\mathrm{SA}$ for human-adapted IAVs [201,202]. Another example is the gram-negative bacterium Pseudomonas aeruginosa, which can cause various diseases in humans, such as bacteremia, chronic pulmonary infection, urinary tract infection and acute ulcerative keratitis. It has two lectins, LecA and LecB, respectively binding the galactose and fucose residues of glycoconjugates on epithelial cells of various tissues. With these two lectins, P. aeruginosa can recognize and infect the lung or other host cell tissues [32]. Another gram-negative bacterium, $H$. pylori that causes gastritis, stomach ulcers, and stomach cancer, has different lectins on the cell surfaces $[203,204]$. These lectins recognize the carbohydrate residues on the 
cell surface of the gastric mucosa to mediate H. pylori infection. Among several lectins in H. pylori outer membrane, the blood group antigen-binding adhesin (BabA) and the lacdiNAc-binding adhesin (LabA) are well studied. BabA binds fucosylated residues of Lewis b antigen and $\mathrm{H1}$ antigen, and LabA binds $\mathrm{N}, \mathrm{N}^{\prime}$-diacetyllactosediamine residues, these two residues are carried by the mucin MUC5AC in human gastric surface epithelia $[17,33]$. Magalhaes et al. demonstrated that $\alpha(1,2)$ fucosyltransferase deficient mice resulted in the inhibition of the fucosylation of Lewis $b$, leading to the significant reduction of H. pylori infection [205].

The pathogen lectins can also suppress the immunity of hosts. A notable example is the C-type lectin. C-type lectin is a class of animal-specific lectin that can possess the $\mathrm{Ca}^{2+}$-dependent sugar recognition activity on the cell surface. Several C-type lectins can be secreted by animal-parasitic nematodes (APNs): Tc-CTL-1 and Tc-CTL-4 secreted by Toxocara canis, CTL1/2 released by Heligmosomoides polygyrus and Nippostrongylus brasiliensis [206-208]. These C-type lectins share the similar sequence to the immune cell lectins in their mammalian hosts, suggesting these proteins are involved in distinct roles in immune evasion [209]. Moreover, the pathogen-secreted lectins can mask the PAMP chitin from the cell wall by binding the oligosaccharides to evade immune surveillance of hosts, and these lectins include Slp1 from Magnaporthe oryzae [21], Ecp6 from Cladosporium fulvum [34], and LysM1 from Trichophyton rubrum [35]. Alternatively, pathogen-secreted lectins might also suppress the host immune response by disturbing the sucrose signal. The lectin calreticulin $[210,211] \mathrm{Mi}-\mathrm{CRT}$ secreted by Meloidogyne incognita [212] can inhibit the PAMP-triggered immunity (PTI) elicited by ELF18 that derives from the $\mathrm{N}$-terminal of bacterial elongation factor-Tu. The C-type lectin $\mathrm{Mg} 01965$ secreted by M. graminicola can suppress the PTI induced by flg22 which is a PAMP from the N-terminal of bacterial flagellin [131]. The above two lectins are unlikely to mask oligosaccharides, since carbohydrate residues are absent in ELF18 and flg22. In plants, endogenous sugar or sugar complex often involves in signal transduction. Indeed, local increases in certain sugar levels have been found under biotic stresses [213-215]. Shifts in apoplastic/cell sugar content may be sensed by plants and lead to the induction of immunity [215]. Therefore, the pathogen lectins may affect the signal transduction through binding endogenous sugar or sugar complex to suppress the immune responses [216,217].

\subsection{Host Lectins}

Host lectins are normally beneficial in pathogen resistance through inhibiting pathogen growth and reproduction or inducing the host immune responses. The animal or plant lectins can inhibit the development of various pathogens including fungi, bacteria, and parasites. For example, a lectin with hemagglutinating activity extracted from Phaseolus vulgaris can inhibit the growth of the fungi Valsa mali [218]; the lectin PSL isolated from Pisum sativum seeds exhibits antifungal activity against Aspergillus flavus, Trichoderma viride and Fusarium oxysporum [36]; a chitin-binding lectin isolated from Solanum tuberosum shows antibacterial activity against Listeria monocytogenes, E. coli, Salmonella enteritidis [219]; the lectin BpLec from Bothrops pauloensis snake venom decreases replication of the parasite Toxoplasma gondii [37]. Host lectins can bind peptidoglycans, polysaccharides, lipopolysaccharides (LPSs) or teichuronic acids on the pathogen surface to disturb the cell wall function and thus restrain pathogens [220].

Membrane-bound lectins of hosts can recognize pathogens by the glycans on the pathogen surface, and transmit signals to trigger immune responses. One example is the mincle that can mediate immune responses to resist infection from various pathogens [221]. In mice, the mincle participates in the immune response against Candida albicans. The cell wall of $C$. albicans contains $\alpha$-mannosyl or $\mathrm{N}$-acetylglucosamine residues with specific geometry. It can be specifically bound by a common carbohydrate-binding domain consisting of Glu-Pro-Asn that presents in mice. These glycan residues activate mouse mincle and trigger the Syk/Card pathway to effectively activate Nuclear Factor kappa-B $(\mathrm{NF}-\mathrm{KB})$ signaling. Such a process increases the cytokine expression levels, and consequently prevents the C. albicans infection $[38,222]$. 
In some cases, however, host lectins can also be deleterious when it is used by pathogens. Different from the aforementioned mouse mincle, the human mincle can act as a negative regulatory factor to inhibit immune responses. Fonsecaea monophora is a causative agent of chronic fungal skin infection. The $\beta$-glucan on F. monophora cell wall can trigger the host lectin Dectin- 1 on the surface of dendritic cells (DCs). Then Dectin-1 activates the transcription factor interferon regulatory factor 1 (IRF1), which is vital for $I L-12 A$ transcription, and consequently triggers $\mathrm{T}_{\mathrm{H}} 1$ and $\mathrm{T}_{\mathrm{H}} 17$ immune responses against the fungus $[40,223,224]$. However, in this process, the human mincle on the surface of DCs is simultaneously triggered by the pathogen via proper carbohydrate molecule(s). Activated mincle induces degradation of IRF1 in the nucleus through an E3 ubiquitin ligase Mdm2-dependent degradation pathway. This process is deleterious for antifungal defense, as it leads to the loss of nuclear IRF1 activity and blocks IL-12A transcription [40].

Host lectins may act as spies to help pathogen transmission and dissemination. During the host antiviral response, the lectin DC-SIGN on the DCs surface binds the virus surface glycan, and subsequently "eats" and "digests" the virus by endocytosis and lysosomes [225]. Alternatively, after DCs catch the virus it migrates to lymphoid organs where DCs present the antigens of the virus to CD4 ${ }^{+}$ $\mathrm{T}$ cells, and then trigger the adaptive immune response to effectively prevent virus infection [226-228]. This mechanism can be also utilized by some viruses. For instance, the host expressing DC-SIGN can enhance the transmission and dissemination of human immunodeficiency virus type 1 (HIV-1). HIV-1 causes acquired immune deficiency syndrome in humans by targeting $\mathrm{CD} 4^{+} \mathrm{T}$ cells $[229,230]$. In the early stages of infection, this targeting is less efficient, as the concentration for virus or $\mathrm{CD} 4^{+} \mathrm{T}$ cells is often very low at the infection sites [231]. Once HIV-1 enters the host, even in a very low concentration, it will be immediately captured by DCs via DC-SIGN [41]. This case is different from DC-SIGN mediated "eat" and "digest", instead DC-SIGN can enrich the virus on the DCs surface and helps to retain HIV-1 infectivity [232]. Afterward, DCs carry the enriched HIV-1 to the lymphoid organs which rich in $\mathrm{CD}^{+}{ }^{+} \mathrm{T}$ cells, and finally HIV-1 is enriched and transmitted to target cells [233-235]. In addition, DC-SIGN can also interact with Dengue virus [233], Hepatitis C virus [236], Sindbis virus [237], and the West Nile virus [42] via glycans that present on viral envelope glycoproteins and then participate in virus attachment to DCs for an efficiency infection.

\section{Conclusions}

Protein is an indispensable constituent of organism and plays a wide spectrum of functions in an organism. Generally, proteins need undergo different types of post-translational modifications for maturation and activation, and glycosylation is one of the most important among them [10]. It is employed mainly in six aspects in the host-pathogen interaction: (I) host glycoproteins separate pathogens from host as barriers; (II) host glycoproteins entrap the pathogen by specific interaction via carbohydrates with adhesins of the pathogen; (III) pathogen glycoproteins act as weapons to attack the host; (IV) hosts sense pathogen glycoproteins to induce resistance; (V) pathogen proteins are glycosylated in the host ER and turn pathogenic; (VI) pathogen proteins can glycosylate host proteins to cause disease (Figure 2). The activities of glycosylation on the host-pathogen interaction are attributed to the glycans that frequently alter the properties of proteins. The spatial structure of carbohydrate residues affects the conformation of proteins and masks specific sites of proteins or the hydrophilia of carbohydrate residues. The protein solubility is subsequently affected, resulting in a change of the protein activity, stability, or antigenicity. The glycans also act as nutrients for microbes or a mimic of cell wall components to directly inhibit pathogens. Investigating the role of protein glycosylation in host-pathogen interaction is significant in basic science since it provides a better understanding of host-pathogen interaction mechanism and its evolutionary inference, while it also sounds in applied science as it can be used to vaccine development, disease diagnosis, and drug therapy. 


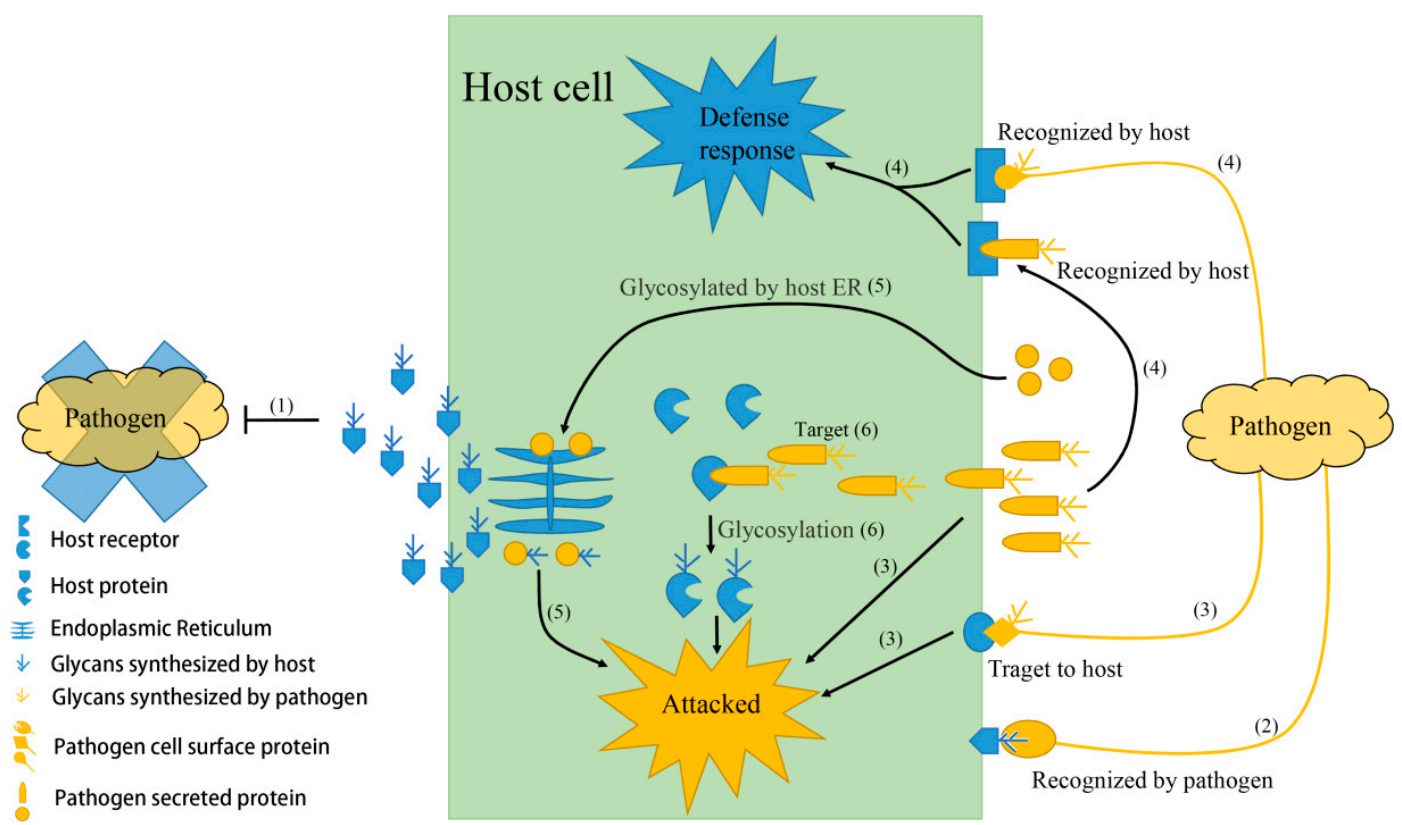

Figure 2. Schematic depicting the multiple functions of glycoproteins in host-pathogen interaction. (1) Glycoproteins surround the host cell act as barriers to inhibit pathogen adhesion, growth or kill pathogens; (2) alternatively these glycoproteins are recognized by pathogens to promote infection; (3) pathogen cell-surface or secreted glycoproteins directly cause disease; (4) alternatively these pathogen glycoproteins are recognized by host receptors to trigger defense responses; (5) pathogens also secrete non-glycoproteins to hosts and, subsequently be glycosylated in host endoplasmic reticulum (ER) before they turn pathogenic; (6) proteins secreted from pathogens can target and glycosylate key proteins of host intracellular signal pathway to cause disease.

Author Contributions: K.Z. and B.L. contributed to the conception and design of the layout and prepared the manuscript; X.Q. and J.L. contributed to revising the manuscript. All authors have read and agreed to the published version of the manuscript.

Funding: This work was supported by grants from the National Natural Science Foundation of China (31772136, 31972246 and 31601614).

Conflicts of Interest: The authors declare no conflict of interest.

\section{References}

1. Ohtsubo, K.; Marth, J.D. Glycosylation in cellular mechanisms of health and disease. Cell 2006, 126, 855-867. [CrossRef] [PubMed]

2. Varki, A. Biological roles of glycans. Glycobiology 2017, 27, 3-49. [CrossRef]

3. Struwe, W.B.; Robinson, C.V. Relating glycoprotein structural heterogeneity to function - insights from native mass spectrometry. Curr. Opin. Struc. Biol. 2019. [CrossRef]

4. Rudd, P.M.; Elliott, T.; Cresswell, P.; Wilson, I.A.; Dwek, R.A. Glycosylation and the immune system. Science 2001, 291, 2370-2376. [CrossRef] [PubMed]

5. Pagano, M.R.; Mendieta, J.R.; Munoz, F.F.; Daleo, G.R.; Guevara, M.G. Roles of glycosylation on the antifungal activity and apoplast accumulation of StAPs (Solanum tuberosum aspartic proteases). Int. J. Biol. Macromol. 2007, 41, 512-520. [CrossRef] [PubMed]

6. Yan, Q.J.; Qi, X.W.; Jiang, Z.Q.; Yang, S.Q.; Han, L.J. Characterization of a pathogenesis-related class 10 protein (PR-10) from Astragalus mongholicus with ribonuclease activity. Plant Physiol. Biochem. 2008, 46, 93-99. [CrossRef]

7. Park, J.I.; Semyonov, J.; Chang, C.L.; Hsu, S.Y.T. Conservation of the heterodimeric glycoprotein hormone subunit family proteins and the LGR signaling system from nematodes to humans. Endocrine 2005, 26, 267-276. [CrossRef] 
8. Shinkawa, T.; Nakamura, K.; Yamane, N.; Shoji-Hosaka, E.; Kanda, Y.; Sakurada, M.; Uchida, K.; Anazawa, H.; Satoh, M.; Yamasaki, M.; et al. The absence of fucose but not the presence of galactose or bisecting $\mathrm{N}$-acetylglucosamine of human IgG1 complex-type oligosaccharides shows the critical role of enhancing antibody-dependent cellular cytotoxicity. J. Biol. Chem. 2003, 278, 3466-3473. [CrossRef]

9. Su, Y.P.; Bakker, T.; Harris, J.; Tsang, C.; Brown, G.D.; Wormald, M.R.; Gordon, S.; Dwek, R.A.; Rudd, P.M.; Martinez-Pomares, L. Glycosylation influences the lectin activities of the macrophage mannose receptor. J. Biol. Chem. 2005, 280, 32811-32820. [CrossRef]

10. Tytgat, H.L.P.; de Vos, W.M. Sucar coating the envelope: Glycoconjucates for microbe-host crosstalk. Trends Microbiol. 2016, 24, 853-861. [CrossRef]

11. Bann, J.G.; Peyton, D.H.; Bachinger, H.P. Sweet is stable: Glycosylation stabilizes collagen. FEBS Lett. 2000, 473, 237-240. [CrossRef]

12. Sano, K.; Asahi, M.; Yanagibashi, M.; Hashii, N.; Itoh, S.; Kawasaki, N.; Ogawa, H. Glycosylation and ligand-binding activities of rat plasma fibronectin during liver regeneration after partial hepatectomy. Carbohydr. Res. 2008, 343, 2329-2335. [CrossRef] [PubMed]

13. Johansson, M.E.V.; Larsson, J.M.H.; Hansson, G.C. The two mucus layers of colon are organized by the MUC2 mucin, whereas the outer layer is a legislator of host-microbial interactions. Proc. Natl. Acad. Sci. USA 2011, 108, 4659-4665. [CrossRef] [PubMed]

14. Arike, L.; Hansson, G.C. The densely O-glycosylated MUC2 mucin protects the intestine and provides food for the commensal bacteria. J. Mol. Biol. 2016, 428, 3221-3229. [CrossRef] [PubMed]

15. Hasnain, S.Z.; Wang, H.Q.; Ghia, J.E.; Haq, N.; Deng, Y.K.; Velcich, A.; Grencis, R.K.; Thornton, D.J.; Khan, W.I. Mucin gene deficiency in mice impairs host resistance to an enteric parasitic infection. Gastroenterology 2010, 138, 1763-1771. [CrossRef]

16. Kawakubo, M.; Ito, Y.; Okimura, Y.; Kobayashi, M.; Sakura, K.; Kasama, S.; Fukuda, M.N.; Fukuda, M.; Katsuyama, T.; Nakayama, J. Natural antibiotic function of a human gastric mucin against Helicobacter pylori infection. Science 2004, 305, 1003-1006. [CrossRef]

17. Rossez, Y.; Gosset, P.; Boneca, I.G.; Magalhaes, A.; Ecobichon, C.; Reis, C.A.; Cieniewski-Bernard, C.; Curt, M.J.C.; Leonard, R.; Maes, E.; et al. The LacdiNAc-specific adhesin LabA mediates adhesion of Helicobacter pylori to human gastric mucosa. J. Infect. Dis. 2014, 210, 1286-1295. [CrossRef]

18. Chen, Y.; Dong, W.; Tan, L.; Held, M.A.; Kieliszewski, M.J. Arabinosylation plays a crucial role in extensin cross-linking in vitro. Biochem. Insights 2015, 8, 1-13. [CrossRef]

19. Guevara, M.G.; Oliva, C.R.; Huarte, M.; Daleo, G.R. An aspartic protease with antimicrobial activity is induced after infection and wounding in intercellular fluids of potato tubers. Eur. J. Plant Pathol. 2002, 108, 131-137. [CrossRef]

20. Grass, S.; Lichti, C.F.; Townsend, R.R.; Gross, J.; St Geme, J.W. The Haemophilus influenzae HMW1C protein is a glycosyltransferase that transfers hexose residues to asparagine sites in the HMW1 adhesin. PLoS Pathog. 2010, 6, e1000919. [CrossRef]

21. Mentlak, T.A.; Kombrink, A.; Shinya, T.; Ryder, L.S.; Otomo, I.; Saitoh, H.; Terauchi, R.; Nishizawa, Y.; Shibuya, N.; Thomma, B.; et al. Effector-mediated suppression of chitin-triggered immunity by Magnaporthe oryzae is necessary for rice blast disease. Plant Cell 2012, 24, 322-335. [CrossRef]

22. Chen, X.L.; Shi, T.; Yang, J.; Shi, W.; Gao, X.S.; Chen, D.; Xu, X.W.; Xu, J.R.; Talbot, N.J.; Peng, Y.L. $\mathrm{N}$-Glycosylation of effector proteins by an alpha-1,3-mannosyltransferase is required for the rice blast fungus to evade host innate immunity. Plant Cell 2014, 26, 1360-1376. [CrossRef] [PubMed]

23. Qi, F.F.; Zhang, W.X.; Zhang, F.J.; Chen, G.J.; Liu, W.F. Deciphering the effect of the different n-glycosylation sites on the secretion, activity, and stability of cellobiohydrolase i from Trichoderma reesei. Appl. Environ. Microbiol. 2014, 80, 3962-3971. [CrossRef] [PubMed]

24. Sun, W.X.; Jia, Y.J.; Feng, B.Z.; O’Neill, N.R.; Zhu, X.P.; Xie, B.Y.; Zhang, X.G. Functional analysis of Pcipg2 From the straminopilous plant pathogen Phytophthora capsici. Genesis 2009, 47, 535-544. [CrossRef] [PubMed]

25. Chen, J.S.; Lin, B.R.; Huang, Q.L.; Hu, L.L.; Zhuo, K.; Liao, J.L. A novel Meloidogyne graminicola effector, $\mathrm{MgGPP}$, is secreted into host cells and undergoes glycosylation in concert with proteolysis to suppress plant defenses and promote parasitism. PLoS Pathog. 2017, 13, e1006301. [CrossRef]

26. Chen, S.; Lang, P.; Chronis, D.; Zhang, S.; De Jong, W.S.; Mitchum, M.G.; Wang, X. In planta processing and glycosylation of a nematode clavata3/endosperm surrounding region-like effector and its interaction with a host CLAVATA2-like receptor to promote parasitism. Plant Physiol. 2015, 167, 262-272. [CrossRef] 
27. Papatheodorou, P.; Zamboglou, C.; Genisyuerek, S.; Guttenberg, G.; Aktories, K. Clostridial glucosylating toxins enter cells via clathrin-mediated endocytosis. PLoS ONE 2010, 5, e10673. [CrossRef]

28. Kotze, A.C.; McClure, S.J. Haemonchus contortus utilises catalase in defence against exogenous hydrogen peroxide in vitro. Int. J. Parasitol. 2001, 31, 1563-1571. [CrossRef]

29. Wang, W.; Owen, S.M.; Rudolph, D.L.; Cole, A.M.; Hong, T.; Waring, A.J.; Lal, R.B.; Lehrer, R.I. Activity of alpha- and theta-defensins against primary isolates of HIV-1. J. Immunol. 2004, 173, 515-520. [CrossRef]

30. Lescar, J.; Roussel, A.; Wien, M.W.; Navaza, J.; Fuller, S.D.; Wengler, G.; Wengler, G.; Rey, F.A. The fusion glycoprotein shell of Semliki Forest virus: An icosahedral assembly primed for fusogenic activation at endosomal pH. Cell 2001, 105, 137-148. [CrossRef]

31. Leikina, E.; Delanoe-Ayari, H.; Melikov, K.; Cho, M.S.; Chen, A.; Waring, A.J.; Wang, W.; Xie, Y.M.; Loo, J.A.; Lehrer, R.I.; et al. Carbohydrate-binding molecules inhibit viral fusion and entry by crosslinking membrane glycoproteins. Nat. Immunol. 2005, 6, 995-1001. [CrossRef]

32. Chemani, C.; Imberty, A.; de Bentzmann, S.; Pierre, M.; Wimmerova, M.; Guery, B.P.; Faure, K. Role of LecA and LecB lectins in Pseudomonas aeruginosa-induced lung injury and effect of carbohydrate ligands. Infect. Immun. 2009, 77, 2065-2075. [CrossRef] [PubMed]

33. Ilver, D.; Arnqvist, A.; Ogren, J.; Frick, I.-M.; Kersulyte, D.; Incecik, E.T.; Berg, D.E.; Covacci, A.; Engstrand, L.; Boren, T. Helicobacter pylori adhesin binding fucosylated histo-blood group antigens revealed by retagging. Science 1998, 279, 373-377. [CrossRef] [PubMed]

34. De Jonge, R.; van Esse, H.P.; Kombrink, A.; Shinya, T.; Desaki, Y.; Bours, R.; van der Krol, S.; Shibuya, N.; Joosten, M.; Thomma, B. Conserved fungal LysM effector Ecp6 prevents chitin-triggered immunity in plants. Science 2010, 329, 953-955. [CrossRef] [PubMed]

35. Kar, B.; Patel, P.; Free, S.J. Trichophyton rubrum LysM proteins bind to fungal cell wall chitin and to the $N$-linked oligosaccharides present on human skin glycoproteins. PLoS ONE 2019, 14, 19. [CrossRef]

36. Sitohy, M.; Doheim, M.; Badr, H. Isolation and characterization of a lectin with antifungal activity from Egyptian Pisum sativum seeds. Food Chem. 2007, 104, 971-979. [CrossRef]

37. Castanheira, L.; de Souza, D.L.N.; Silva, R.J.; Barbosa, B.; Mineo, J.R.; Tudini, K.A.; Rodrigues, R.; Ferro, E.V.; Rodrigues, V.D. Insights into anti-parasitism induced by a C-type lectin from Bothrops pauloensis venom on Toxoplasma gondii. Int. J. Biol. Macromol. 2015, 74, 568-574. [CrossRef]

38. Balch, S.G.; Greaves, D.R.; Gordon, S.; McKnight, A.J. Organization of the mouse macrophage C-type lectin,(Mcl) gene and identification of a subgroup of related lectin molecules. Eur. J. Immunogenet. 2002, 29, 61-64. [CrossRef]

39. Wells, C.A.; Salvage-Jones, J.A.; Li, X.; Hitchens, K.; Butcher, S.; Murray, R.Z.; Beckhouse, A.G.; Lo, Y.L.S.; Manzanero, S.; Cobbold, C.; et al. The macrophage-inducible C-type lectin, Mincle, is an essential component of the innate immune response to Candida albicans. J. Immunol. 2008, 180, 7404-7413. [CrossRef]

40. Wevers, B.A.; Kaptein, T.M.; Zijlstra-Willems, E.M.; Theelen, B.; Boekhout, T.; Geijtenbeek, T.B.H.; Gringhuis, S.I. Fungal engagement of the C-Type lectin mincle suppresses Dectin-1-induced antifungal immunity. Cell Host Microbe 2014, 15, 494-505. [CrossRef]

41. Geijtenbeek, T.B.H.; Kwon, D.S.; Torensma, R.; van Vliet, S.J.; van Duijnhoven, G.C.F.; Middel, J.; Cornelissen, I.L.M.H.A.; Nottet, H.S.L.M.; KewalRamani, V.N.; Littman, D.R.; et al. DC-SIGN, a dendritic cell-specific HIV-1-binding protein that enhances trans-infection of T cells. Cell 2000, 100, 587-597. [CrossRef]

42. Davis, C.W.; Nguyen, H.Y.; Hanna, S.L.; Sanchez, M.D.; Doms, R.W.; Pierson, T.C. West Nile virus discriminates between DC-SIGN and DC-SIGNR for cellular attachment and infection. J. Virol. 2006, 80, 1290-1301. [CrossRef] [PubMed]

43. Hachisu, M.; Ito, Y. Chemical approaches to elucidate enzymatic profiles of UDP-glucose: Glycoprotein glucosyltransferase. Chem. Pharm. Bull. 2016, 64, 687-690. [CrossRef] [PubMed]

44. Alton, G.; Hasilik, M.; Niehues, R.; Panneerselvam, K.; Etchison, J.R.; Fana, F.; Freeze, H.H. Direct utilization of mannose for mammalian glycoproteinn biosynthesis. Glycobiology 1998, 8, 285-295. [CrossRef] [PubMed]

45. Tian, C.; Wang, M.M.; Liu, S.S.; Ma, H.; He, K.; Zhou, D.Q.; Li, Y.L.; Ye, X.L.; Li, X.G. A new glycoprotein SPG-8700 isolated from sweet potato with potential anti-cancer activity against colon cancer. Nat. Prod. Res. 2019, 33, 2322-2328. [CrossRef] [PubMed]

46. Zhang, L.; Paasch, B.C.; Chen, J.; Day, B.; He, S.Y. An important role of L-fucose biosynthesis and protein fucosylation genes in Arabidopsis immunity. New Phytol. 2019, 222, 981-994. [CrossRef] [PubMed] 
47. Chesnokov, V.; Gong, B.; Sun, C.; Itakura, K. Anti-cancer activity of glucosamine through inhibition of $N$-linked glycosylation. Cancer Cell Int. 2014, 14, 10. [CrossRef]

48. Agarwal, K.; Kaul, R.; Garg, M.; Shajahan, A.; Jha, S.K.; Sampathkumar, S.G. Inhibition of mucin-type $O$-glycosylation through metabolic processing and incorporation of $N$-thioglycolyl-d-galactosamine peracetate (Ac(5)GalNTGc). J. Am. Chem. Soc. 2013, 135, 14189-14197. [CrossRef]

49. Qi, L.; Kash, J.C.; Dugan, V.G.; Wang, R.X.; Jin, G.Z.; Cunningham, R.E.; Taubenberger, J.K. Role of sialic acid binding specificity of the 1918 Influenza virus hemagglutinin protein in virulence and pathogenesis for mice. J. Virol. 2009, 83, 3754-3761. [CrossRef]

50. Hou, L.L.; Li, T.S.; Chen, H.Y.; Shen, D.F.; Li, M.J.; Guo, Y.M.; Zou, L.; Wang, L.; Sun, G.Q.; Cai, W.M.; et al. Identification and characterization of a novel glycoprotein core xylosidase from the bacterium Elizabethkingia meningoseptica. Biochem. Biophys. Res. Commun. 2019, 517, 390-397. [CrossRef]

51. Gamblin, D.P.; Scanlan, E.M.; Davis, B.G. Glycoprotein synthesis: An update. Chem. Rev. 2009, 109, $131-163$. [CrossRef]

52. Southwood, D.; Ranganathan, S. Host-pathogen interactions. In Encyclopedia of Bioinformatics and Computational Biology; Elsevier: Amsterdam, The Netherlands, 2019; Volume 3, pp. 103-112.

53. Gudesblat, G.E.; Torres, P.S.; Vojnov, A.A. Stomata and pathogens warfare at the gates. Plant Signal. Behav. 2009, 4, 1114-1116. [CrossRef]

54. Van Niekerk, J.M.; Halleen, F.; Fourie, P.H. Temporal susceptibility of grapevine pruning wounds to trunk pathogen infection in South African grapevines. Phytopathol. Mediterr. 2011, 50, S139-S150.

55. Nagamine, T.; Inaba, T.; Sako, Y. A nuclear envelop-associated baculovirus protein promotes intranuclear lipid accumulation during infection. Virology 2019, 532, 108-117. [CrossRef] [PubMed]

56. Mitchum, M.G.; Hussey, R.S.; Baum, T.J.; Wang, X.H.; Elling, A.A.; Wubben, M.; Davis, E.L. Nematode effector proteins: An emerging paradigm of parasitism. New Phytol. 2013, 199, 879-894. [CrossRef]

57. Wawra, S.; Belmonte, R.; Lobach, L.; Saraiva, M.; Willems, A.; van West, P. Secretion, delivery and function of oomycete effector proteins. Curr. Opin. Microbiol. 2012, 15, 685-691. [CrossRef]

58. Shames, S.R.; Finlay, B.B. Bacterial effector interplay: A new way to view effector function. Trends Microbiol. 2012, 20, 214-219. [CrossRef]

59. Ma, L.S.; Wang, L.; Trippel, C.; Mendoza-Mendoza, A.; Ullmann, S.; Moretti, M.; Carsten, A.; Kahnt, J.; Reissmann, S.; Zechmann, B.; et al. The Ustilago maydis repetitive effector Rsp3 blocks the antifungal activity of mannose-binding maize proteins. Nat. Commun. 2018, 9, 15. [CrossRef]

60. Goverse, A.; Smant, G. The activation and suppression of plant innate immunity by parasitic nematodes. Annu. Rev. Phytopathol. 2014, 52, 243-265. [CrossRef]

61. Hou, S.; Zhang, C.; Yang, Y.; Wu, D. Recent advances in plant immunity: Recognition, signaling, response, and evolution. Biol. Plantarum 2013, 57, 11-25. [CrossRef]

62. Arthur, J.S.C.; Ley, S.C. Mitogen-activated protein kinases in innate immunity. Nat. Rev. Immunol. 2013, 13, 679-692. [CrossRef]

63. Chen, Y.; Chen, J.; Wang, H.; Shi, J.; Wu, K.; Liu, S.; Liu, Y.; Wu, J. HCV-Induced miR-21 Contributes to evasion of host immune system by targeting MyD88 and IRAK1. PLoS Pathog. 2013, 9, e1003248. [CrossRef] [PubMed]

64. Dyer, M.D.; Murali, T.M.; Sobral, B.W. The landscape of human proteins interacting with viruses and other pathogens. PLoS Pathog. 2008, 4, 14. [CrossRef] [PubMed]

65. Lin, B.R.; Zhuo, K.; Chen, S.Y.; Hu, L.L.; Sun, L.H.; Wang, X.H.; Zhang, L.H.; Liao, J.L. A novel nematode effector suppresses plant immunity by activating host reactive oxygen species-scavenging system. New Phytol. 2016, 209, 1159-1173. [CrossRef] [PubMed]

66. Kotzin, J.J.; Mowel, W.K.; Henao-Mejia, J. Viruses hijack a host lncRNA to replicate Viruses induce a host lncRNA to rewire cellular metabolism to promote their replication. Science 2017, 358, 993-994. [CrossRef] [PubMed]

67. Jiang, J.; Smith, H.N.; Ren, D.; Mudiyanselage, S.D.D.; Dawe, A.L.; Wang, L.; Wang, Y. Potato Spindle Tuber viroid modulates its replication through a direct interaction with a splicing regulator. J. Virol. 2018, 92, 9. [CrossRef]

68. Favery, B.; Quentin, M.; Jaubert-Possamai, S.; Abad, P. Gall-forming root-knot nematodes hijack key plant cellular functions to induce multinucleate and hypertrophied feeding cells. J. Insect Physiol. 2016, 84, 60-69. [CrossRef] 
69. Morozov, V.; Borkowski, J.; Hanisch, F.G. The double face of mucin-type O-glycans in lectin-mediated infection and immunity. Molecules 2018, 23, 14. [CrossRef]

70. Hooper, L.V.; Gordon, J.I. Glycans as legislators of host-microbial interactions: Spanning the spectrum from symbiosis to pathogenicity. Glycobiology 2001, 11, 1R-10R. [CrossRef] [PubMed]

71. Bhat, A.H.; Maity, S.; Giri, K.; Ambatipudi, K. Protein glycosylation: Sweet or bitter for bacterial pathogens? Crit. Rev. Microbiol. 2019, 45, 82-102. [CrossRef]

72. Wang, W.-H.; Lin, C.-Y.; Chang, M.R.; Urbina, A.N.; Assavalapsakul, W.; Thitithanyanont, A.; Chen, Y.-H.; Liu, F.-T.; Wang, S.-F. The role of galectins in virus infection - A systemic literature review. J. Microbiol. Immunol. 2019. [CrossRef]

73. Jones, J.D.G.; Dangl, J.L. The plant immune system. Nature 2006, 444, 323-329. [CrossRef]

74. Netea, M.G.; Joosten, L.A.B.; Latz, E.; Mills, K.H.G.; Natoli, G.; Stunnenberg, H.G.; O’Neill, L.A.J.; Xavier, R.J. Trained immunity: A program of innate immune memory in health and disease. Science 2016, 352. [CrossRef] [PubMed]

75. Corfield, A.P. Mucins: A biologically relevant glycan barrier in mucosal protection. Biochim. Biophys. Acta Gen. Subj. 2015, 1850, 236-252. [CrossRef] [PubMed]

76. Castilleux, R.; Plancot, B.; Ropitaux, M.; Carreras, A.; Leprince, J.; Boulogne, I.; Follet-Gueye, M.L.; Popper, Z.A.; Driouich, A.; Vicre, M. Cell wall extensins in root-microbe interactions and root secretions. J. Exp. Bot. 2018, 69, 4235-4247. [CrossRef]

77. Mendieta, J.R.; Pagano, M.R.; Munoz, F.F.; Daleo, G.R.; Guevara, M.G. Antimicrobial activity of potato aspartic proteases (StAPs) involves membrane permeabilization. Microbiology 2006, 152, 2039-2047. [CrossRef]

78. Engevik, M.A.; Luk, B.; Chang-Graham, A.L.; Hall, A.; Herrmann, B.; Ruan, W.; Endres, B.T.; Shi, Z.C.; Garey, K.W.; Hyser, J.M.; et al. Bifidobacterium dentium fortifies the intestinal mucus layer via autophagy and calcium signaling pathways. Mbio 2019, 10. [CrossRef]

79. Katayama, T.; Fujita, K.; Yamamoto, K. Novel bifidobacterial glycosidases acting on sugar chains of mucin glycoproteins. J. Biosci. Bioeng. 2005, 99, 457-465. [CrossRef]

80. Miller, H.R. Gastrointestinal mucus, a medium for survival and for elimination of parasitic nematodes and protozoa. Parasitology 1987, 94, S77-S100. [CrossRef]

81. Yamauchi, J.; Kawai, Y.; Yamada, M.; Uchikawa, R.; Tegoshi, T.; Arizono, N. Altered expression of goblet cell- and mucin glycosylation-related genes in the intestinal epithelium during infection with the nematode Nippostrongylus brasiliensis in rat. APMIS 2006, 114, 270-278. [CrossRef]

82. Hasnain, S.Z.; Gaagher, A.L.; Grencis, R.K.; Thornton, D.J. A new role for mucins in immunity: Insights from gastrointestinal nematode infection. Int. J. Biochem. Cell Biol. 2013, 45, 364-374. [CrossRef]

83. Douch, P.G.; Harrison, G.B.; Buchanan, L.L.; Greer, K.S. In vitro bioassay of sheep gastrointestinal mucus for nematode paralysing activity mediated by substances with some properties characteristic of SRS-A. Int. J. Parasitol. 1983, 13, 207-212. [CrossRef]

84. Webb, R.A.; Hoque, T.; Dimas, S. Expulsion of the gastrointestinal cestode, Hymenolepis diminuta by tolerant rats: Evidence for mediation by a Th2 type immune enhanced goblet cell hyperplasia, increased mucin production and secretion. Parasite Immunol. 2007, 29, 11-21. [CrossRef]

85. Carlisle, M.S.; McGregor, D.D.; Appleton, J.A. Intestinal mucus entrapment of Trichinella spiralis larvae induced by specific antibodies. Immunology 1991, 74, 546-551. [PubMed]

86. Kardon, R.; Price, R.E.; Julian, J.; Lagow, E.; Tseng, S.C.G.; Gendler, S.J.; Carson, D.D. Bacterial conjunctivitis in Muc1 null mice. Investig. Ophthalmol. Vis. Sci. 1999, 40, 1328-1335.

87. Lamport, D.T.A.; Northcote, D.H. Hydroxyproline in primary cell walls of higher plants. Nature 1960, 188, 665-666. [CrossRef]

88. Malinovsky, F.G.; Fangel, J.U.; Willats, W.G.T. The role of the cell wall in plant immunity. Front. Plant Sci. 2014, 5. [CrossRef]

89. Otulak-Koziel, K.; Koziel, E.; Lockhart, B.E.L. Plant cell wall dynamics in compatible and incompatible potato response to infection caused by Potato Virus Y (PVYNTN). Int. J. Mol. Sci. 2018, 19, 862. [CrossRef]

90. Jackson, P.A.P.; Galinha, C.I.R.; Pereira, C.S.; Fortunato, A.; Soares, N.C.; Amancio, S.B.Q.; Pinto Ricardo, C.P. Rapid deposition of extensin during the elicitation of grapevine callus cultures is specifically catalyzed by a 40-kilodalton peroxidase. Plant Physiol. 2001, 127, 1065-1076. [CrossRef] 
91. Li, Y.Y.; Chen, X.M.; Zhang, Y.; Cho, Y.H.; Wang, A.R.; Yeung, E.C.; Zeng, X.; Guo, S.X.; Lee, Y.I. Immunolocalization and changes of hydroxyproline-rich glycoproteins during symbiotic germination of Dendrobium officinale. Front. Plant Sci. 2018, 9. [CrossRef]

92. Basavaraju, P.; Shailasree, S.; Shetty, N.P.; Kini, R.K.; Jorgensen, H.J.L.; de Neergaard, E.; Shetty, H.S. Infection induced oxidative cross-linking of hydroxyproline-rich glycoproteins (HRGPs) is associated with restriction of Colletotrichum sublineolum in sorghum. J. Plant Interact. 2009, 4, 179-186. [CrossRef]

93. Marco, M.L.; Pavan, S.; Kleerebezem, M. Towards understanding molecular modes of probiotic action. Curr. Opin. Biotechnol. 2006, 17, 204-210. [CrossRef]

94. Turroni, F.; Ventura, M.; Butto, L.F.; Duranti, S.; O’Toole, P.W.; Motherway, M.O.; van Sinderen, D. Molecular dialogue between the human gut microbiota and the host: A Lactobacillus and Bifidobacterium perspective. Cell. Mol. Life Sci. 2014, 71, 183-203. [CrossRef]

95. Zuniga, M.; Monedero, V.; Yebra, M.J. Utilization of host-derived glycans by intestinal Lactobacillus and Bifidobacterium species. Front. Microbiol. 2018, 9. [CrossRef] [PubMed]

96. Collado, M.C.; Grzeskowiak, L.; Salminen, S. Probiotic strains and their combination inhibit in vitro adhesion of pathogens to pig intestinal mucosa. Curr. Microbiol. 2007, 55, 260-265. [CrossRef] [PubMed]

97. Peek, R.M.; Blaser, M.J. Helicobacter pylori and gastrointestinal tract adenocarcinomas. Nat. Rev. Cancer 2002, 2, 28-37. [CrossRef] [PubMed]

98. Cave, D.R. Chronic gastritis and Helicobacter pylori. Semin. Gastrointest. Dis. 2001, 12, 196-202.

99. Guevara, M.G.; Verissimo, P.; Pires, E.; Faro, C.; Daleo, G.R. Potato aspartic proteases: Induction, antimicrobial activity and substrate specificity. J. Plant Pathol. 2004, 86, 233-238.

100. Muenzner, P.; Tchoupa, A.K.; Klauser, B.; Brunner, T.; Putze, J.; Dobrindt, U.; Hauck, C.R. Uropathogenic E. coli exploit CEA to promote colonization of the urogenital tract mucosa. PLoS Pathog. 2016, 12, e1005608. [CrossRef]

101. Grass, S.; Buscher, A.Z.; Swords, W.E.; Apicella, M.A.; Barenkamp, S.J.; Ozchlewski, N.; St Geme, J.W. The Haemophilus influenzae HMW1 adhesin is glycosylated in a process that requires HMW1C and phosphoglucomutase, an enzyme involved in lipooligosaccharide biosynthesis. Mol. Microbiol. 2003, 48, 737-751. [CrossRef]

102. Singh, R.S.; Walia, A.K.; Kanwar, J.R. Protozoa lectins and their role in host-pathogen interactions. Biotechnol. Adv. 2016, 34, 1018-1029. [CrossRef]

103. De Groot, P.W.J.; de Boer, A.D.; Cunningham, J.; Dekker, H.L.; de Jong, L.; Hellingwerf, K.J.; de Koster, C.; Klis, F.M. Proteomic analysis of Candida albicans cell walls reveals covalently bound carbohydrate-active enzymes and adhesins. Eukaryot. Cell 2004, 3, 955-965. [CrossRef]

104. St Geme, J.W., 3rd; Falkow, S.; Barenkamp, S.J. High-molecular-weight proteins of nontypable Haemophilus influenzae mediate attachment to human epithelial cells. Proc. Natl. Acad. Sci. USA 1993, 90, 2875-2879. [CrossRef] [PubMed]

105. Grass, S.; St. Geme, J.W., III. Maturation and secretion of the non-typable Haemophilus influenzae HMW1 adhesin: Roles of the N-terminal and C-terminal domains. Mol. Microbiol. 2000, 36, 55-67. [CrossRef] [PubMed]

106. Li, S.; Zhang, L.; Yao, Q.; Li, L.; Dong, N.; Rong, J.; Gao, W.Q.; Ding, X.J.; Sun, L.M.; Chen, X.; et al. Pathogen blocks host death receptor signalling by arginine GlcNAcylation of death domains. Nature 2013, 501, 242-246. [CrossRef]

107. Chen, S.Y.; Sun, C.L.; Wang, H.Y.; Wang, J.F. The Role of Rho GTPases in Toxicity of Clostridium difficile Toxins. Toxins 2015, 7, 5254-5267. [CrossRef] [PubMed]

108. Just, I.; Wilm, M.; Selzer, J.; Rex, G.; Von Eichel-Streiber, C.; Mann, M.; Aktories, K. The enterotoxin from Clostridium difficile (ToxA) monoglucosylates the Rho proteins. J. Biol. Chem. 1995, 270, 13932-13936. [CrossRef] [PubMed]

109. Just, I.; Selzer, J.; Wilm, M.; Von Eichel-Streiber, C.; Mann, M.; Aktories, K. Glucosylation of Rho proteins by Clostridium difficile toxin B. Nature 1995, 375, 500-503. [CrossRef] [PubMed]

110. Just, I.; Selzer, J.; Hofmann, F.; Green, G.A.; Aktories, K. Inactivation of Ras by Clostridium sordellii lethal toxin-catalyzed glucosylation. J. Biol. Chem. 1996, 271, 10149-10153. [CrossRef]

111. Pertz, O. Spatio-temporal Rho GTPase signaling - where are we now? J. Cell Sci. 2010, 123, 1841-1850. [CrossRef] 
112. Ottlinger, M.E.; Lin, S. Clostridium difficile toxin B induces reorganization of actin, vinculin, and talin in cultured cells. Exp. Cell Res. 1988, 174, 215-229. [CrossRef]

113. Subauste, M.C.; Von Herrath, M.; Benard, V.; Chamberlain, C.E.; Chuang, T.-H.; Chu, K.; Bokoch, G.M.; Hahn, K.M. Rho family proteins modulate rapid apoptosis induced by cytotoxic T lymphocytes and Fas. J. Biol. Chem. 2000, 275, 9725-9733. [CrossRef] [PubMed]

114. Caron, E.; Hall, A. Identification of two distinct mechanisms of phagocytosis controlled by different Rho GTPases. Science 1998, 282, 1717-1721. [CrossRef] [PubMed]

115. Shin, M.H.; Kita, H.; Park, H.Y.; Seoh, J.Y. Cysteine protease secreted by Paragonimus westermani attenuates effector functions of human eosinophils stimulated with immunoglobulin G. Infect. Immun. 2001, 69, 1599-1604. [CrossRef]

116. Knox, D.P.; Redmond, D.L.; Skuce, P.J.; Newlands, G.F.J. The contribution of molecular biology to the development of vaccines against nematode and trematode parasites of domestic ruminants. Vet. Parasitol. 2001, 101, 311-335. [CrossRef]

117. Redmond, D.L.; Knox, D.P. Further protection studies using recombinant forms of Haemonchus contortus cysteine proteinases. Parasite Immunol. 2006, 28, 213-219. [CrossRef]

118. Gibbons, D.L.; Vaney, M.C.; Roussel, A.; Vigouroux, A.; Reilly, B.; Lepault, J.; Kielian, M.; Rey, F.A. Conformational change and protein protein interactions of the fusion protein of Semliki Forest virus. Nature 2004, 427, 320-325. [CrossRef]

119. Peumans, W.J.; Van Damme, E.J.M. Lectins as plant defense proteins. Plant Physiol. 1995, 109, $347-352$. [CrossRef]

120. Sharon, N.; Lis, H. Lectins: Cell-agglutinating and sugar-specific proteins. Science 1972, 177, 949-959. [CrossRef]

121. Myhill, N.; Lynes, E.M.; Nanji, J.A.; Blagoveshchenskaya, A.D.; Fei, H.; Simmen, K.C.; Cooper, T.J.; Thomas, G.; Simmen, T. The subcellular distribution of calnexin is mediated by PACS-2. Mol. Biol. Cell 2008, 19, 2777-2788. [CrossRef]

122. Okazaki, Y.; Ohno, H.; Takase, K.; Ochiai, T.; Saito, T. Cell surface expression of calnexin, a molecular chaperone in the endoplasmic reticulum. J. Biol. Chem. 2000, 275, 35751-35758. [CrossRef]

123. Williams, D.B. Beyond lectins: The calnexin/calreticulin chaperone system of the endoplasmic reticulum. J. Cell Sci. 2006, 119, 615-623. [CrossRef]

124. Satoh, T.; Cowieson, N.P.; Hakamata, W.; Ideo, H.; Fukushima, K.; Kurihara, M.; Kato, R.; Yamashita, K.; Wakatsuki, S. Structural basis for recognition of high mannose type glycoproteins by mammalian transport lectin VIP36. J. Biol. Chem. 2007, 282, 28246-28255. [CrossRef]

125. Appenzeller, C.; Andersson, H.; Kappeler, F.; Hauri, H.P. The lectin ERGIC-53 is a cargo transport receptor for glycoproteins. Nat. Cell Biol. 1999, 1, 330-334. [CrossRef] [PubMed]

126. Munro, S. The MRH domain suggests a shared ancestry for the mannose 6-phosphate receptors and other N-glycan-recognising proteins. Curr. Biol. 2001, 11, R499-R501. [CrossRef]

127. Rohrer, J.; Kornfeld, R. Lysosomal hydrolase mannose 6-phosphate uncovering enzyme resides in the trans-Golgi network. Mol. Biol. Cell 2001, 12, 1623-1631. [CrossRef]

128. Bleekemolen, J.E.; Stein, M.; von Figura, K.; Slot, J.W.; Geuze, H.J. The two mannose 6-phosphate receptors have almost identical subcellular distributions in U937 monocytes. Eur. J. Cell Biol. 1988, 47, 366-372. [PubMed]

129. Scheel, G.; Herzog, V. Mannose 6-phosphate receptor in porcine thyroid follicle cells. Localization and possible implications for the intracellular transport of thyroglobulin. Eur. J. Cell Biol. 1989, 49, 140-148. [PubMed]

130. Waguri, S.; Kohmura, M.; Kanamori, S.; Watanabe, T.; Ohsawa, Y.; Koike, M.; Tomiyama, Y.; Wakasugi, M.; Kominami, E.; Uchiyama, Y. Different distribution patterns of the two mannose 6-phosphate receptors in rat liver. J. Histochem. Cytochem. 2001, 49, 1397-1405. [CrossRef] [PubMed]

131. Zhuo, K.; Naalden, D.; Nowak, S.; Huy, N.X.; Bauters, L.; Gheysen, G. A Meloidogyne graminicola C-type lectin, Mg01965, is secreted into the host apoplast to suppress plant defence and promote parasitism. Mol. Plant Pathol. 2019, 20, 346-355. [CrossRef] [PubMed]

132. Swaminathan, G.J.; Leonidas, D.D.; Savage, M.P.; Ackerman, S.J.; Acharya, K.R. Selective recognition of mannose by the human eosinophil Charcot-Leyden crystal protein (galectin-10): A crystallographic study at 1.8 ANG resolution. Biochemistry 1999, 38, 13837-13843. [CrossRef] 
133. Garner, O.B.; Baum, L.G. Galectin-glycan lattices regulate cell-surface glycoprotein organization and signalling. Biochem. Soc. Trans. 2008, 36, 1472-1477. [CrossRef]

134. Vyakarnam, A.; Dagher, S.F.; Wang, J.L.; Patterson, R.J. Evidence for a role for galectin-1 in pre-mRNA splicing. Mol. Cell. Biol. 1997, 17, 4730-4737. [CrossRef] [PubMed]

135. Sano, H.; Hsu, D.K.; Apgar, J.R.; Yu, L.; Sharma, B.B.; Kuwabara, I.; Izui, S.; Liu, F.T. Critical role of galectin-3 in phagocytosis by macrophages. J. Clin. Investig. 2003, 112, 389-397. [CrossRef] [PubMed]

136. Paz, I.; Sachse, M.; Dupont, N.; Mounier, J.; Cederfur, C.; Enninga, J.; Leffler, H.; Poirier, F.; Prevost, M.C.; Lafont, F.; et al. Galectin-3, a marker for vacuole lysis by invasive pathogens. Cell Microbiol. 2010, 12, 530-544. [CrossRef] [PubMed]

137. Shi, W.-X.; Chammas, R.; Varki, N.M.; Powell, L.; Varki, A. Sialic acid 9-O-acetylation on murine erythroleukemia cells affects complement activation, binding to I-type lectins, and tissue homing. J. Biol. Chem. 1996, 271, 31526-31532. [CrossRef] [PubMed]

138. Warren, H.S.; Altin, J.G.; Waldron, J.C.; Kinnear, B.F.; Parish, C.R. A carbohydrate structure associated with CD15 (Lewis-X) on myeloid cells is a novel ligand for human CD2. J. Immunol. 1996, 156, 2866-2873. [PubMed]

139. Heiland, P.C.; Griffith, L.S.; Lange, R.; Schachner, M.; Hertlein, B.; Traub, O.; Schmitz, B. Tyrosine and serine phosphorylation of the neural cell adhesion molecule L1 is implicated in its oligomannosidic glycan dependent association with NCAM and neurite outgrowth. Eur. J. Cell Biol. 1998, 75, 97-106. [CrossRef]

140. Kim, D.H.; Patnaik, B.B.; Seo, G.W.; Kang, S.M.; Lee, Y.S.; Lee, B.L.; Han, Y.S. Identification and expression analysis of a novel R-type lectin from the coleopteran beetle, Tenebrio molitor. J. Invertebr. Pathol. 2013, 114, 226-229. [CrossRef]

141. Suzuki, R.; Kuno, A.; Hasegawa, T.; Hirabayashi, J.; Kasai, K.I.; Momma, M.; Fujimoto, Z. Sugar-complex structures of the C-half domain of the galactose-binding lectin EW29 from the earthworm Lumbricus terrestris. Acta Crystallogr. Sect. D-Struct. Biol. 2009, 65, 49-57. [CrossRef]

142. Hasan, I.; Gerdol, M.; Fujii, Y.; Rajia, S.; Koide, Y.; Yamamoto, D.; Kawsar, S.M.A.; Ozeki, Y. cDNA and gene structure of MytiLec-1, a bacteriostatic R-Type lectin from the mediterranean mussel (Mytilus galloprovincialis). Mar. Drugs 2016, 14, 14. [CrossRef]

143. Kallio, H.; Tolvanen, M.; Janis, J.; Pan, P.W.; Laurila, E.; Kallioniemi, A.; Kilpinen, S.; Tuominen, V.J.; Isola, J.; Valjakka, J.; et al. Characterization of non-specific cytotoxic cell receptor protein 1: A new member of the lectin-type subfamily of f-box proteins. PLOS ONE 2011, 6, 16. [CrossRef]

144. Ren, Y.; Ding, Q.; Zhang, X. Ficolins and infectious diseases. Virol. Sin. 2014, 29, 25-32. [CrossRef]

145. Kakinuma, Y.; Endo, Y.; Takahashi, M.; Nakata, M.; Matsushita, M.; Takenoshita, S.; Fujita, T. Molecular cloning and characterization of novel ficolins from Xenopus laevis. Immunogenetics 2003, 55, 29-37. [CrossRef]

146. Itik, V.; Kemik, O.; Kemik, A.; Dulger, A.C.; Sumer, A.; Soyoral, Y.U.; Begenik, H.; Purisa, S.; Kotan, C. Serum YKL-40 Levels in Patients with Gastric Cancer. Biomark. Cancer 2011, 3, 25-30. [CrossRef]

147. Cai, Y.P.; Kumar, R.K.; Zhou, J.S.; Foster, P.S.; Webb, D.C. Ym1/2 promotes Th2 cytokine expression by inhibiting 12/15(S)-lipoxygenase: Identification of a novel pathway for regulating allergic inflammation. J. Immunol. 2009, 182, 5393-5399. [CrossRef]

148. Kan, F.W.K.; Esperanzate, P.W.B. Surface mapping of binding of oviductin to the plasma membrane of golden hamster spermatozoa during in vitro capacitation and acrosome reaction. Mol. Reprod. Dev. 2006, 73, 756-766. [CrossRef]

149. Odom, E.W.; Vasta, G.R. Characterization of a binary tandem domain F-type lectin from striped bass (Morone saxatilis). J. Biol. Chem. 2006, 281, 1698-1713. [CrossRef]

150. Salerno, G.; Parisi, M.G.; Parrinello, D.; Benenati, G.; Vizzini, A.; Vazzana, M.; Vasta, G.R.; Cammarata, M. F-type lectin from the sea bass (Dicentrarchus labrax): Purification, cDNA cloning, tissue expression and localization, and opsonic activity. Fish Shellfish Immunol. 2009, 27, 143-153. [CrossRef]

151. Voehringer, D.; Stanley, S.A.; Cox, J.S.; Completo, G.C.; Lowary, T.L.; Locksley, R.M. Nippostrongylus brasiliensis: Identification of intelectin-1 and -2 as Stat6-dependent genes expressed in lung and intestine during infection. Exp. Parasitol. 2007, 116, 458-466. [CrossRef]

152. Tsuji, S.; Yamashita, M.; Nishiyama, A.; Shinohara, T.; Zhongwei, U.; Myrvik, Q.N.; Hoffman, D.R.; Henriksen, R.A.; Shibata, Y. Differential structure and activity between human and mouse intelectin-1: Human intelectin-1 is a disulfide-linked trimer, whereas mouse homologue is a monomer. Glycobiology 2007, 17, 1045-1051. [CrossRef] 
153. Nagata, S. Isolation, characterization, and extra-embryonic secretion of the Xenopus laevis embryonic epidermal lectin, XEEL. Glycobiology 2005, 15, 281-290. [CrossRef]

154. Wu, A.M.; Liu, J.H.; Gong, Y.P.; Li, C.C.; Chang, E.T. Multiple recognition systems adopting four different glycotopes at the same domain for the Agaricus bisporus agglutinin-glycan interactions. FEBS Lett. 2010, 584, 3561-3566. [CrossRef]

155. Peumans, W.J.; Fouquaert, E.; Jauneau, A.; Rouge, P.; Lannoo, N.; Hamada, H.; Alvarez, R.; Devreese, B.; Van Damme, E.J.M. The liverwort Marchantia polymorpha expresses orthologs of the fungal Agaricus bisporus agglutinin family. Plant Physiol. 2007, 144, 637-647. [CrossRef]

156. Rosen, S.; Sjollema, K.; Veenhuis, M.; Tunlid, A. A cytoplasmic lectin produced by the fungus Arthrobotrys oligospora functions as a storage protein during saprophytic and parasitic growth. Microbiology 1997, 143, 2593-2604. [CrossRef]

157. Rinderle, S.J.; Goldstein, I.J.; Remsen, E.E. Physicochemical properties of amaranthin, the lectin from Amaranthus caudatus seeds. Biochemistry 1990, 29, 10555-10561. [CrossRef]

158. Faruque, K.; Begam, R.; Deyholos, M.K. The Amaranthin-Like lectin (LuALL) genes of flax: A unique gene family with members inducible by defence hormones. Plant Mol. Biol. Rep. 2015, 33, 731-741. [CrossRef]

159. Dang, L.Y.; Rouge, P.; Van Damme, E.J.M. Amaranthin-like proteins with aerolysin domains in plants. Front. Plant Sci. 2017, 8. [CrossRef]

160. Sulzenbacher, G.; Roig-Zamboni, V.; Peumans, W.J.; Henrissat, B.; van Damme, E.J.M.; Bourne, Y. Structural basis for carbohydrate binding properties of a plant chitinase-like agglutinin with conserved catalytic machinery. J. Struct. Biol. 2015, 190, 115-121. [CrossRef]

161. Van Damme, E.J.M.; Culerrier, R.; Barre, A.; Alvarez, R.; Rouge, P.; Peumans, W.J. A novel family of lectins evolutionarily related to class V chitinases: An example of neofunctionalization in legumes. Plant Physiol. 2007, 144, 662-672. [CrossRef]

162. Woodrum, B.W.; Maxwell, J.D.; Bolia, A.; Ozkan, S.B.; Ghirlanda, G. The antiviral lectin cyanovirin-N: Probing multivalency and glycan recognition through experimental and computational approaches. Biochem. Soc. Trans. 2013, 41, 1170-1176. [CrossRef]

163. Van Hove, J.; Fouquaert, E.; Smith, D.F.; Proost, P.; Van Damme, E.J.M. Lectin activity of the nucleocytoplasmic EUL protein from Arabidopsis thaliana. Biochem. Biophys. Res. Commun. 2011, 414, 101-105. [CrossRef]

164. Yamamoto, S. Anti-B activity of a lectin coexistent with blood group H-like substance in seeds of Euonymus sieboldiana. Int. J. Immunogenet. 1976, 3, 163-170. [CrossRef]

165. Li, D.K.; Wang, X.Y.; Yuan, D.Z.; Zhang, L.; Jiang, X.; Tao, Z.W.; Li, Y.; Wang, J.M.; Li, X.F.; Yang, Y. Over-expression of ArathEULS3 confers ABA sensitivity and drought tolerance in Arabidopsis. Plant Cell Tissue Organ Cult. 2014, 117, 431-442. [CrossRef]

166. Van Damme, E.J.M.; Nakamura-Tsuruta, S.; Smith, D.F.; Ongenaert, M.; Winter, H.C.; Rouge, P.; Goldstein, I.J.; Mo, H.; Kominami, J.; Culerrier, R.; et al. Phylogenetic and specificity studies of two-domain GNA-related lectins: Generation of multispecificity through domain duplication and divergent evolution. Biochem. J. 2007, 404, 51-61. [CrossRef]

167. Fouquaert, E.; Peumans, W.J.; Van Damme, E.J.M. Confocal microscopy confirms the presumed cytoplasmic/nuclear location of plant, fish and fungal orthologs of the Galanthus nivalis agglutinin. Commun. Agric. Appl. Biol. Sci. 2006, 71, 141-144.

168. Fouquaert, E.; Hanton, S.L.; Brandizzi, F.; Peumans, W.J.; Van Damme, E.J.M. Localization and topogenesis studies of cytoplasmic and vacuolar homologs of the Galanthus nivalis agglutinin. Plant Cell Physiol. 2007, 48, 1010-1021. [CrossRef]

169. Lee, H.I.; Broekaert, W.F.; Raikhel, N.V.; Lee, H. Co- and post-translational processing of the hevein preproprotein of latex of the rubber tree (Hevea brasiliensis). J. Biol. Chem. 1991, 266, 15944-15948.

170. Soedjanaatmadja, U.M.S.; Subroto, T.; Beintema, J.J. Processed products of the hevein precursor in the latex of the rubber tree (Hevea brasiliensis). FEBS Lett. 1995, 363, 211-213. [CrossRef]

171. Rojas, E.; Llinas, P.; Rodriguez-Romero, A.; Hernandez, C.; Linares, M.; Zenteno, E.; Lascurain, R. Hevein, an allergenic lectin from rubber latex, activates human neutrophils' oxidative burst. Glycoconj. J. 2001, 18, 339-345. [CrossRef]

172. Van Damme, E.J.; Peumans, W.J.; Barre, A.; Rouge, P. Plant lectins: A composite of several distinct families of structurally and evolutionary related proteins with diverse biological roles. Crit. Rev. Plant Sci. 1998, 17, 575-692. [CrossRef] 
173. Young, N.M.; Watson, D.C.; Thibault, P. Mass spectrometric analysis of genetic and post-translational heterogeneity in the lectins jacalin and Maclura pomifera agglutinin. Glycoconj. J. 1995, 12, 135-141. [CrossRef]

174. Peumans, W.J.; Hause, B.; Van Damme, E.J.M. The galactose-binding and mannose-binding jacalin-related lectins are located in different sub-cellular compartments. FEBS Lett. 2000, 477, 186-192. [CrossRef]

175. Chisholm, S.T.; Parra, M.A.; Anderberg, R.J.; Carrington, J.C. Arabidopsis RTM1 and RTM2 genes function in phloem to restrict long-distance movement of Tobacco Etch virus. Plant Physiol. 2001, 127, 1667-1675. [CrossRef]

176. Chen, J.; Liu, B.; Ji, N.; Zhou, J.; Bian, H.J.; Li, C.Y.; Chen, F.; Bao, J.K. A novel sialic acid-specific lectin from Phaseolus coccineus seeds with potent antineoplastic and antifungal activities. Phytomedicine 2009, 16, 352-360. [CrossRef]

177. Liu, Z.; Liu, B.; Zhang, Z.T.; Zhou, T.T.; Bian, H.J.; Min, M.W.; Liu, Y.H.; Chen, J.; Bao, J.K. A mannose-binding lectin from Sophora flavescens induces apoptosis in HeLa cells. Phytomedicine 2008, 15, 867-875. [CrossRef]

178. Qureshi, I.A.; Dash, P.; Srivastava, P.S.; Koundal, K.R. Purification and characterization of an $N$-acetyl-D-galactosamine-specific lectin from seeds of chickpea (Cider arietinum L.). Phytochem. Anal. 2006, 17, 350-356. [CrossRef]

179. Barre, A.; Herve, C.; Lescure, B.; Rouge, P. Lectin receptor kinases in plants. Crit. Rev. Plant Sci. 2002, 21, 379-399. [CrossRef]

180. Limpens, E.; Franken, C.; Smit, P.; Willemse, J.; Bisseling, T.; Geurts, R. LysM domain receptor kinases regulating rhizobial Nod factor-induced infection. Science 2003, 302, 630-633. [CrossRef]

181. Madsen, E.B.; Madsen, L.H.; Radutoiu, S.; Olbryt, M.; Rakwalska, M.; Szczyglowski, K.; Sato, S.; Kaneko, T.; Tabata, S.; Sandal, N.; et al. A receptor kinase gene of the LysM type is involved in legume perception of rhizobial signals. Nature 2003, 425, 637-640. [CrossRef]

182. He, J.M.; Zhang, C.; Dai, H.L.; Liu, H.; Zhang, X.W.; Yang, J.; Chen, X.; Zhu, Y.Y.; Wang, D.P.; Qi, X.F.; et al. A LysM receptor heteromer mediates perception of arbuscular mycorrhizal symbiotic signal in rice. Mol. Plant 2019, 12, 1561-1576. [CrossRef]

183. Radutoiu, S.; Madsen, L.H.; Madsen, E.B.; Felle, H.H.; Umehara, Y.; Gronlund, M.; Sato, S.; Nakamura, Y.; Tabata, S.; Sandal, N.; et al. Plant recognition of symbiotic bacteria requires two LysM receptor-like kinases. Nature 2003, 425, 585-592. [CrossRef]

184. Stefanowicz, K.; Lannoo, N.; Proost, P.; Van Damme, E.J.M. Arabidopsis F-box protein containing a Nictaba-related lectin domain interacts with $N$-acetyllactosamine structures. FEBS Open Bio 2012, 2, 151-158. [CrossRef] [PubMed]

185. Lannoo, N.; Peumans, W.J.; Van Pamel, E.; Alvarez, R.; Xiong, T.C.; Hause, G.; Mazars, C.; Van Damme, E.J.M. Localization and in vitro binding studies suggest that the cytoplasmic/nuclear tobacco lectin can interact in situ with high-mannose and complex N-glycans. FEBS Lett. 2006, 580, 6329-6337. [CrossRef] [PubMed]

186. Van Holle, S.; Smagghe, G.; Van Damme, E.J.M. Overexpression of Nictaba-Like lectin genes from glycine max confers tolerance toward Pseudomonas syringae infection, aphid infestation and salt stress in transgenic arabidopsis plants. Front. Plant Sci. 2016, 7, 17. [CrossRef] [PubMed]

187. Yoon, H.S.; Kang, C.B.; Song, S.K.; Ye, W.; Nanga, R.P.R.; Song, J.-H. Molecular characterization of the recombinant a-chain of a Type II ribosome-inactivating protein (RIP) from Viscum album coloratum and structural basis on its ribosome-inactivating activity. BMB Rep. 2006, 39, 560-570.

188. Kozlov, Y.V.; Sudarkina, O.Y.; Kurmanova, A.G. Ribosome-inactivating lectins of plants. Mol. Biol. 2006, 40, 711-723. [CrossRef]

189. Bandyopadhyay, S.; Roy, A.; Das, S. Binding of garlic (Allium sativum) leaf lectin to the gut receptors of homopteran pests is correlated to its insecticidal activity. Plant Sci. 2001, 161, 1025-1033. [CrossRef]

190. Loris, R.; De Greve, H.; Dao-Thi, M.-H.; Messens, J.; Imberty, A.; Wyns, L. Structural basis of carbohydrate recognition by lectin II from Ulex europaeus, a protein with a promiscuous carbohydrate-binding site. J. Mol. Biol. 2000, 301, 987-1002. [CrossRef]

191. Sarray, S.; Berthet, V.; Calvete, J.J.; Secchi, J.; Marvaldi, J.; El Ayeb, M.; Marrakchi, N.; Luis, J. Lebectin, a novel C-type lectin from Macrovipera lebetina venom, inhibits integrin-mediated adhesion, migration and invasion of human tumor cells. Lab. Investig. 2004, 84, 573-581. [CrossRef]

192. Rapoport, E.M.; Kurmyshkina, O.V.; Bovin, N.V. Mammalian galectins: Structure, carbohydrate specificity, and functions. Biochemistry-Moscow 2008, 73, 393-405. [CrossRef] 
193. Baigent, S.J.; McCauley, J.W. Influenza type A in humans, mammals and birds: Determinants of virus virulence, host-range and interspecies transmission. Bioessays 2003, 25, 657-671. [CrossRef]

194. Wang, Y.N.; Narain, R.; Liu, Y. Study of bacterial adhesion on different glycopolymer surfaces by quartz crystal microbalance with dissipation. Langmuir 2014, 30, 7377-7387. [CrossRef] [PubMed]

195. Rogers, G.N.; Paulson, J.C. Receptor determinants of human and animal influenza virus isolates: Differences in receptor specificity of the H3 hemagglutinin based on species of origin. Virology 1983, 127, 361-373. [CrossRef]

196. Smrt, S.T.; Lorieau, J.L. Membrane Fusion and Infection of the Influenza Hemagglutinin. Adv. Exp. Med. Biol. 2017, 966, 37-54. [CrossRef] [PubMed]

197. Xiong, X.L.; McCauley, J.W.; Steinhauer, D.A. Receptor binding properties of the influenza virus hemagglutinin as a determinant of host range. In Influenza Pathogenesis and Control-Vol I; Compans, R.W., Oldstone, M.B.A., Eds.; Springer: Cham, Switzerland, 2014; Volume 385, pp. 63-91.

198. Couceiro, J.N.; Paulson, J.C.; Baum, L.G. Influenza virus strains selectively recognize sialyloligosaccharides on human respiratory epithelium; the role of the host cell in selection of hemagglutinin receptor specificity. Virus Res. 1993, 29, 155-165. [CrossRef]

199. Shinya, K.; Ebina, M.; Yamada, S.; Ono, M.; Kasai, N.; Kawaoka, Y. Influenza virus receptors in the human airway. Nature 2006, 440, 435-436. [CrossRef]

200. Gagneux, P.; Cheriyan, M.; Hurtado-Ziola, N.; van der Linden, E.; Anderson, D.; McClure, H.; Varki, A.; Varki, N.M. Human-specific regulation of alpha 2-6-linked sialic acids. J. Biol. Chem. 2003, 278, 48245-48250. [CrossRef] [PubMed]

201. Chandrasekaran, A.; Srinivasan, A.; Raman, R.; Viswanathan, K.; Raguram, S.; Tumpey, T.M.; Sasisekharan, V.; Sasisekharan, R. Glycan topology determines human adaptation of avian H5N1 virus hemagglutinin. Nat. Biotechnol. 2008, 26, 107-113. [CrossRef] [PubMed]

202. Matrosovich, M.; Tuzikov, A.; Bovin, N.; Gambaryan, A.; Klimov, A.; Castrucci, M.R.; Donatelli, I.; Kawaoka, Y. Early alterations of the receptor-binding properties of $\mathrm{H} 1, \mathrm{H} 2$, and $\mathrm{H} 3$ avian influenza virus hemagglutinins after their introduction into mammals. J. Virol. 2000, 74, 8502-8512. [CrossRef]

203. Griffiths, A.E.; Sumiya, M.; Summerfield, J.; Cheng, S.; Murray, E.; Eggleton, P.; Sim, R.; Walker, M.; Karim, N.; Thursz, M. The codon 52 mutation in the mannose binding lectin gene predisposes to Helicobacter pylori infection. Gastroenterology 1999, 116, A727.

204. Worthley, D.L.; Mullighan, C.G.; Dean, M.M.; Gordon, D.L.; Philips, P.; Heatley, S.; Young, G.P.; Bardy, P.G. Mannose-binding lectin deficiency does not increase the prevalence of Helicobacter pylori seropositivity. Eur. J. Gastroenterol. Hepatol. 2007, 19, 147-152. [CrossRef]

205. Magalhaes, A.; Gomes, J.; Ismail, M.N.; Haslam, S.M.; Mendes, N.; Osorio, H.; David, L.; Lependu, J.; Haas, R.; Dell, A.; et al. Fut2-null mice display an altered gastric mucosa glycosylation profile and modified Helicobacter pylori adhesion. Glycobiology 2010, 20, 1460-1461.

206. Harcus, Y.; Nicoll, G.; Murray, J.; Filbey, K.; Gomez-Escobar, N.; Maizels, R.M. C-type lectins from the nematode parasites Heligmosomoides polygyrus and Nippostrongylus brasiliensis. Parasitol. Int. 2009, 58, 461-470. [CrossRef] [PubMed]

207. Loukas, A.; Doedens, A.; Hintz, M.; Maizels, R.M. Identification of a new C-type lectin, TES-70, secreted by infective larvae of Toxocara canis, which binds to host ligands. Parasitology 2000, 121, 545-554. [CrossRef] [PubMed]

208. Loukas, A.; Mullin, N.P.; Tetteh, K.K.A.; Moens, L.; Maizels, R.M. A novel C-type lectin secreted by a tissue-dwelling parasitic nematode. Curr. Biol. 1999, 9, 825-828. [CrossRef]

209. Loukas, A.; Maizels, R.M. Helminth C-type lectins and host-parasite interactions. Parasitol. Today 2000, 16, 333-339. [CrossRef]

210. Saito, Y.; Ihara, Y.; Leach, M.R.; Cohen-Doyle, M.F.; Williams, D.B. Calreticulin functions in vitro as a molecular chaperone for both glycosylated and non-glycosylated proteins. EMBO J. 1999, 18, 6718-6729. [CrossRef]

211. Thomson, S.P.; Williams, D.B. Delineation of the lectin site of the molecular chaperone calreticulin. Cell Stress Chaperon. 2005, 10, 242-251. [CrossRef]

212. Jaubert, S.; Milac, A.L.; Petrescu, A.J.; de Almelda-Engler, J.; Abad, P.; Rosso, M.N. In planta secretion of a calreticulin by migratory and sedentary stages of root-knot nematode. Mol. Plant Microbe Interact. 2005, 18, 1277-1284. [CrossRef] 
213. Chakraborty, A.; Saha, D.; Bose, A.; Hileman, R.E.; Chatterjee, M.; Gupta, N.K. Mechanism of action of an eukaryotic initiation factor-2 (eIF-2) associated $67 \mathrm{kDa}$ glycoprotein (p67) and an eIF-2 kinase (dsI). Indian J. Biochem. Biophys. 1994, 31, 236-242.

214. Bolouri Moghaddam, M.R.; Van den Ende, W. Sugars and plant innate immunity. J. Exp. Bot. 2012, 63, 3989-3998. [CrossRef]

215. Trouvelot, S.; Heloir, M.C.; Poinssot, B.; Gauthier, A.; Paris, F.; Guillier, C.; Combier, M.; Trda, L.; Daire, X.; Adrian, M. Carbohydrates in plant immunity and plant protection: Roles and potential application as foliar sprays. Front. Plant Sci. 2014, 5, 14. [CrossRef] [PubMed]

216. Van Holle, S.; Van Damme, E.J.M. Signaling through plant lectins: Modulation of plant immunity and beyond. Biochem. Soc. Trans. 2018, 46, 217-233. [CrossRef] [PubMed]

217. Zachara, N.E.; O’Donnell, N.; Cheung, W.D.; Mercer, J.J.; Marth, J.D.; Hart, G.W. Dynamic O-GlcNAc modification of nucleocytoplasmic proteins in response to stress - A survival response of mammalian cells. J. Biol. Chem. 2004, 279, 30133-30142. [CrossRef] [PubMed]

218. Lam, S.K.; Ng, T.B. Isolation and characterization of a French bean hemagglutinin with antitumor, antifungal, and anti-HIV-1 reverse transcriptase activities and an exceptionally high yield. Phytomedicine 2010, 17, 457-462. [CrossRef] [PubMed]

219. Hasan, I.; Ozeki, Y.; Kabir, S.R. Purification of a novel chitin-binding lectin with antimicrobial and antibiofilm activities from a Bangladeshi cultivar of potato (Solanum tuberosum). Indian J. Biochem. Biophys. 2014, 51, 142-148. [PubMed]

220. Iordache, F.; Ionita, M.; Mitrea, L.I.; Fafaneata, C.; Pop, A. Antimicrobial and Antiparasitic Activity of Lectins. Curr. Pharm. Biotechno. 2015, 16, 152-161. [CrossRef]

221. Sica, A.; Mantovani, A. Macrophage plasticity and polarization: In vivo veritas. J. Clin. Investig. 2012, 122, 787-795. [CrossRef]

222. Kijimoto-Ochiai, S. CD23 (the low-affinity IgE receptor) as a C-type lectin: A multidomain and multifunctional molecule. Cell. Mol. Life Sci. 2002, 59, 648-664. [CrossRef]

223. Ip, W.K.E.; Takahashi, K.; Moore, K.J.; Stuart, L.M.; Ezekowitz, R.A.B. Mannose-binding lectin enhances Toll-like receptors 2 and 6 signaling from the phagosome. J. Exp. Med. 2008, 205, 169-181. [CrossRef]

224. Wang, F.P.; Li, Y.H.; Yang, C.; Mu, Y.H.; Wang, Y.; Zhang, W.; Yang, Y.H.; Chen, C.; Song, S.J.; Shen, Z.F.; et al. Mannan-binding lectin suppresses peptidoglycan-induced TLR2 activation and inflammatory responses. Mediat. Inflamm. 2019, 2019, 1-12. [CrossRef]

225. Chatterjee, B.; Smed-Sorensen, A.; Cohn, L.; Chalouni, C.; Vandlen, R.; Lee, B.C.; Widger, J.; Keler, T.; Delamarre, L.; Mellman, I. Internalization and endosomal degradation of receptor-bound antigens regulate the efficiency of cross presentation by human dendritic cells. Blood 2012, 120, 2011-2020. [CrossRef]

226. Engering, A.; Geijtenbeek, T.B.H.; van Vliet, S.J.; Wijers, M.; van Liempt, E.; Demaurex, N.; Lanzavecchia, A.; Fransen, J.; Figdor, C.G.; Piguet, V.; et al. The dendritic cell-specific adhesion receptor DC-SIGN internalizes antigen for presentation to T cells. J. Immunol. 2002, 168, 2118-2126. [CrossRef] [PubMed]

227. Meyer-Wentrup, F.; Benitez-Ribas, D.; Tacken, P.J.; Punt, C.J.A.; Figdor, C.G.; de Vries, I.J.M.; Adema, G.J. Targeting DCIR on human plasmacytoid dendritic cells results in antigen presentation and inhibits IFN-alpha production. Blood 2008, 111, 4245-4253. [CrossRef] [PubMed]

228. LeibundGut-Landmann, S.; Gross, O.; Robinson, M.J.; Osorio, F.; Slack, E.C.; Tsoni, S.V.; Schweighoffer, E.; Tybulewicz, V.; Brown, G.D.; Ruland, J.; et al. Syk- and CARD9-dependent coupling of innate immunity to the induction of $\mathrm{T}$ helper cells that produce interleukin 17. Nat. Immunol. 2007, 8, 630-638. [CrossRef] [PubMed]

229. Douek, D.C.; Brenchley, J.M.; Betts, M.R.; Ambrozak, D.R.; Hill, B.J.; Okamoto, Y.; Casazza, J.P.; Kuruppu, J.; Kuntsman, K.; Wolinsky, S.; et al. HIV preferentially infects HIV-specific CD4(+) T cells. Nature 2002, 417, 95-98. [CrossRef]

230. Hartley, C.A.; Gilbert, M.J.; Brigido, L.; Elbeik, T.; Levy, J.A.; Crowe, S.M.; Mills, J. Human immunodeficiency virus grown in CD4-expressing cells is associated with CD4. J. Gen. Virol. 1996, 77, 2015-2023. [CrossRef]

231. Sedaghat, A.R.; German, J.; Teslovich, T.M.; Cofrancesco, J.; Jie, C.C.; Talbot, C.C.; Siliciano, R.F. Chronic CD4 ${ }^{+}$ T-cell activation and depletion in human immunodeficiency virus type 1 infection: Type I interferon-mediated disruption of T-cell dynamics. J. Virol. 2008, 82, 1870-1883. [CrossRef] 
232. Bermejo-Jambrina, M.; Eder, J.; Helgers, L.C.; Hertoghs, N.; Nijmeijer, B.M.; Stunnenberg, M.; Geijtenbeek, T.B.H. C-Type Lectin Receptors in Antiviral Immunity and Viral Escape. Front. Immunol. 2018, 9, 12. [CrossRef]

233. Tassaneetrithep, B.; Burgess, T.H.; Granelli-Piperno, A.; Trumpfherer, C.; Finke, J.; Sun, W.; Eller, M.A.; Pattanapanyasat, K.; Sarasombath, S.; Birx, D.L.; et al. DC-SIGN (CD209) mediates dengue virus infection of human dendritic cells. J. Exp. Med. 2003, 197, 823-829. [CrossRef]

234. Lambert, A.A.; Gilbert, C.; Richard, M.; Beaulieu, A.D.; Tremblay, M.J. The C-type lectin surface receptor DICIR acts as a new attachment factor for HIV-1 in dendritic cells and contributes to trans- and cis-infection pathways. Blood 2008, 112, 1299-1307. [CrossRef]

235. Nguyen, D.G.; Hildreth, J.E.K. Involvement of macrophage mannose receptor in the binding and transmission of HIV by macrophages. Eur. J. Immunol. 2003, 33, 483-493. [CrossRef]

236. Ludwig, I.S.; Lekkerkerker, A.N.; Depla, E.; Bosman, F.; Musters, R.J.P.; Depraetere, S.; van Kooyk, Y.; Geijtenbeek, T.B.H. Hepatitis C virus targets DC-SIGN and L-SIGN to escape lysosornal degradation. J. Virol. 2004, 78, 8322-8332. [CrossRef] [PubMed]

237. Klimstra, W.B.; Nangle, E.M.; Smith, M.S.; Yurochko, A.D.; Ryman, K.D. DC-SIGN and L-SIGN can act as attachment receptors for alphaviruses and distinguish between mosquito cell- and mammalian cell-derived viruses. J. Virol. 2003, 77, 12022-12032. [CrossRef] [PubMed]

(C) 2020 by the authors. Licensee MDPI, Basel, Switzerland. This article is an open access article distributed under the terms and conditions of the Creative Commons Attribution (CC BY) license (http://creativecommons.org/licenses/by/4.0/). 